\title{
Emerging Molecular Prospective of SARS-CoV-2: Feasible Nanotechnology Based Detection and Inhibition
}

\author{
Sushmita Patra ${ }^{1 \dagger}$, Rout George Kerry ${ }^{2+}$, Ganesh Kumar Maurya ${ }^{3}$, \\ Bijayananda Panigrahi ${ }^{4}$, Swati Kumari ${ }^{4}$ and Jyoti Ranjan Rout ${ }^{5 *}$ \\ 'Department of Biotechnology, North Orissa University, Baripada, India, ${ }^{2}$ Department of Biotechnology, Utkal University, \\ Bhubaneswar, India, ${ }^{3}$ Zoology Section, Mahila Mahavidyalaya, Banaras Hindu University, Varanasi, India, ${ }^{4}$ School \\ of Biotechnology, Kalinga Institute of Industrial Technology, Bhubaneswar, India, ${ }^{5}$ School of Biological Sciences, AIPH \\ University, Bhubaneswar, India
}

OPEN ACCESS

Edited by:

Akio Adachi,

Kansai Medical University, Japan

Reviewed by:

Saeid Ghavami,

University of Manitoba, Canada Boris Michael Hartmann,

Österreichische Agentur für

Gesundheit und

Ernährungssicherheit, Austria

Shemin Lu,

Xi'an Jiaotong University, China

*Correspondence:

Jyoti Ranjan Rout

routir@aiph.ac.in

tThese authors have contributed equally to this work

Specialty section:

This article was submitted to

Virology,

a section of the journal

Frontiers in Microbiology

Received: 22 June 2020 Accepted: 10 August 2020 Published: 20 October 2020

Citation:

Patra S, Kerry RG, Maurya GK, Panigrahi B, Kumari S and Rout JR

(2020) Emerging Molecular

Prospective of SARS-CoV-2: Feasible

Nanotechnology Based Detection

and Inhibition.

Front. Microbiol. 11:2098.

doi: 10.3389/fmicb.2020.02098
The rapid dissemination of SARS-CoV-2 demonstrates how vulnerable it can make communities and is why it has attained the status of global pandemic. According to the estimation from Worldometer, the SARS-CoV-2 affected cases and deaths are exponentially increasing worldwide, marking the mortality rate as $\sim 3.8 \%$ with no probability of its cessation till now. Despite massive attempts and races among scientific communities in search of proper therapeutic options, the termination of this breakneck outbreak of COVID-19 has still not been made possible. Therefore, this review highlights the diverse molecular events induced by a viral infection, such as autophagy, unfolded protein response (UPR), and inflammasome, illustrating the intracellular cascades regulating viral replication inside the host cell. The SARS-CoV-2-mediated endoplasmic reticulum stress and apoptosis are also emphasized in the review. Additionally, host's immune response associated with SARS-CoV-2 infection, as well as the genetic and epigenetic changes, have been demonstrated, which altogether impart a better understanding of its epidemiology. Considering the drawbacks of available diagnostics and medications, herein we have presented the most sensitive nano-based biosensors for the rapid detection of viral components. Moreover, conceptualizing the viral-induced molecular changes inside its target cells, nano-based antiviral systems have also been proposed in this review.

Keywords: autophagy, COVID-19, genetics and epigenetics, inflammasome, nanobased diagnosis, nanobased therapeutics, SARS-CoV-2 pathogenesis

\section{INTRODUCTION}

Pneumonia, an infection of the lungs, is sometimes associated with severe epidemics due to specific viral infections as evidenced in 2002, 2012, and most recently in 2019 due to severe acute respiratory syndrome (SARS), Middle East respiratory syndrome (MERS), and COVID-19, respectively (Christian et al., 2004; Assiri et al., 2013; Sahin et al., 2020). COVID-19 disease caused by severe acute respiratory syndrome coronavirus-2 (SARS-CoV-2) was declared as a global pandemic by the World Health Organization (WHO) on March 11, 2020 (WHO, 2020d). Commencement of 
this viral infection with pneumonia-like symptoms was reported to be associated with a seafood market in Wuhan, China in December, 2019 (Adhikari et al., 2020, Holshue et al., 2020). Afterward, the movement of people during Chinese New Year became a ground for its escalation throughout China and then throughout the globe. Rapid investigations of the clinical manifestation associated with prevailed infection revealed a similar pattern to that of SARS and MERS infections. Severity of COVID-19 infection is associated with some risk factors such as age, obesity, and other specific comorbidities including high blood pressure, pregnancy, diabetes, asthma, and impaired immunity (Guo G. et al., 2020; Petrakis et al., 2020). Within 67 months of its emergence, the virus spread swiftly worldwide, affecting 213 countries and territories with around 18.0 million confirmed cases being reported (Worldometer, 2020). Thus, it has provoked a standstill of life in both developed and developing countries. There is a report of about 18,055,630 COVID-19 cases worldwide with a mortality rate of $\sim 3.8 \%$ (August 2,2020 ), and the cases are expected to increase further (Worldometer, 2020).

There is an urgent need for rapid and efficient methods for SARS-CoV-2 diagnosis and to overcome the present viral outbreak. Currently available diagnostic kits detect the infection from within around $8 \mathrm{~h}$ to $\leq 15 \mathrm{~min}$ (Carter et al., 2020). The viral molecular components, specifically the detection of ORFs encoding pplab, nsp 14, $\mathrm{N}$ protein, $\mathrm{S}$ protein and RNA-dependent RNA polymerase (RdRP) protein, through real time PCR (RT-PCR) methods are being considered. Additionally, the serum-based techniques that employ viral antibodies take less time for diagnosis in comparison to RTPCR methods. However, due to the lack of committed antiviral therapeutics against COVID-19, previously known antiviral strategies involving experimental conventional antiviral drugs used conjointly are being used to treat the symptoms associated with the infection. These drugs are conventionally used in the treatment of other deadly viral/protozoal infections such as HIV/AIDS, influenza virus, Ebola virus, etc. Due to their sideeffects, application of these drugs against this contagious viral infection has become a matter of debate (Corman et al., 2020; Udugama et al., 2020).

These limitations in SARS-CoV-2 detection and effective inhibition could be neutralized by the implementation of nanotechnology. Previously, Gold (Au), Silver (Ag), Graphen, Carbon dots, and Silica (Si) nanoparticles (NPs) have been used for inhibition of a number of viruses (Kerry et al., 2019; Kondel et al., 2019; Lauster et al., 2020). Further, the currently available antiviral drugs barely utilize the emerging molecular intracellular pathways, like autophagy, inflammasome, genetics, and epigenetics, for viral inhibition (Prentice et al., 2004a; Tang et al., 2009; Maier and Britton, 2012; Schafer and Baric, 2017; Fung et al., 2020). In the present review, a detailed outline of the emerging molecular intracellular pathways of SARS-CoV-2 and their significant interactions with host cells are briefly described. Additionally, different types of nanotechnological platforms with possible applications in viral detection and inhibition are also narrated. Specifically, we discuss how the change in the optical property of AuNPs could be exploited in SARS-CoV-2 detection. And how viral antibody conjugated carbon-NPs-coated electrochemical strip could be used for SARS-CoV-2 detection is described from the knowledge and inspiration of previously published and relevant research in virus detection and inhibition (Galluzzi et al., 2017; Chen et al., 2018; Jazayeri et al., 2018; Chowdhury et al., 2019; Siu et al., 2019; Conti et al., 2020; Jena et al., 2020). Moreover, engineering of a cellular-targeted nuclear delivery of antiviral drugs in conjugation with an antisense siRNS or antisense oligonucleotide is also presented for simultaneously sustaining host cell survival and viral inhibition. The antisense siRNS or antisense oligonucleotide can target molecular regulation of autophagy, inflammasome, or endoplasmic reticulum stress of the infected cell, resulting in either inhibiting the viral process within the host cell or armoring the host cell to combat viral infection. Overall, the review could boost scientific innovation to develop an effective and smart diagnostic tool and nanotechnology-based SARS-CoV2 inhibiting agent.

\section{SARS-CoV-2 BASIC INFORMATION}

Coronaviruses belonging to the family Coronaviridae are represented by four genera - alpha $(\alpha)$, beta $(\beta)$, gamma $(\gamma)$, and delta $(\delta)$ - as per the nature of their genetic reservoir, the kind of host, and mode of recombination (Wertheim et al., 2013). The viruses are mostly zoonotic and infect many species of animals, such as camels, cats, bats, and cattle, but have now transferred swiftly to humans. So far, seven such types of human-to-human transmitted coronaviruses have been reported, and these are denominated as 229E and NL63 of genera $\alpha$ coronavirus and OC43, HKU1, SARS-CoV, MERS-CoV, and SARS-CoV-2 of genera $\beta$-coronavirus (Chu D.K.W. et al., 2020). Among all these, SARS, MERS, and COVID-19 are known to be highly pathogenic with a high fatality rate unlike others that are associated with mild upper respiratory tract infections. The world previously had evidenced two coronavirus epidemics caused by SARS-CoV and MERS-CoV in the years of 2002 and 2012, respectively.

The coronavirus is again in the spotlight and has raised alarm across the world after its first official report from Wuhan, China. This time the 2019-CoV was christened as SARS-CoV2 as it is genetically similar to SARS-CoV, and the disease was named COVID-19 (Coronavirus disease 2019) by WHO. Later on, Andersen et al. (2020) suggested that though 2019-CoV holds a $\sim 96 \%$ genetic similarity with RaTG13 bat virus (Rhinolophus sinicus), it has overcome the species-to-species barrier through natural selection (Song et al., 2020). The transmission of the virus to humans occurs through an encounter with infected respiratory aerosols, feces, or through direct contact with the contaminated persons (Xiao et al., 2020). Analysis of several suspected cases indicated that the median incubation period of the virus is around 4.5-5.1 days and symptom onset time is about 11.5-14.5 days (Lauer et al., 2020; Wang X. et al., 2020). The infected persons can be categorized as either symptomatic or asymptomatic, but both have the ability of virus transmission (Gao et al., 2020). However, patient's clinical manifestations include pneumonia, 
non-productive cough, fatigue, fever, acute respiratory distress syndrome (ARDS), standard or decreased leukocyte count, and organ dysfunction, ultimately leading to death (Chu D.K.W. et al., 2020). Due to the novelty of the virus, till now no such specific drugs/vaccines have been formulated to overcome COVID-19, however investigation is under process. Thus, acknowledging the gravity of the situation, an effort has been made to collate novel ideas from different literature, with a hope that this collective review may partially help scientists to find some innovative solutions to shield or combat this deadly disease.

\section{STRUCTURE}

Belonging to the family of Coronaviridae in the order of Nidovirales, SARS-CoV-2 embraces a 30 kilobases long, single positive-stranded RNA genome, endowed with 14 open reading frames (ORFs) and encoding 27 proteins (Wu A. et al., 2020; Zu et al., 2020). The genome is protected by a long, coiled helical capsid of 10-20 nm in diameter, which is further surrounded by an envelope. Whole genome sequence analysis has revealed four main structural proteins, spike (S), envelope (E), membrane $(\mathrm{M})$, and nucleocapsid $(\mathrm{N})$ protein, which are encoded by ORF2, ORF4, ORF5, and ORF9, respectively, present at $3^{\prime}$ terminus constituting about one-third of the viral genome. The transmembrane spike glycoprotein $(150 \mathrm{kDa})$ engrosses into the viral envelope, and the protruding peplomers illustrate a crown-like appearance of the virus. Entry into the host cell is mediated by the attachment of homotrimeric $S$ protein that is cleaved by host cell protease and generates two non-covalently attached functional subunits (Coutard et al., 2020). S1 subunit is a receptor binding domain and determines cellular tropism in several host virus range, while the S2 subunit mediates fusion with the cell membrane (Astuti and Ysrafil, 2020). Both SARSCoV and SARS-CoV-2 share $91.5 \%$ homology in their S protein sequences, but the cleavage site (QTQTNSPRRARSVASQSIIA) is unique to SARS-CoV-2 (Yoshimoto, 2020). The ORF4-encoded smallest $\mathrm{E}$ protein is responsible for viral assembly, release and, thus, maturation. Beneath the spike lies an $M$ protein that provides shape and stability to the virus structure interacting with the $\mathrm{N}$ protein associated with RNA. According to Fehr and Perlman (2015), the binding of the $\mathrm{N}$ protein to the viral genome represents the beads-on-a-string type conformation. $\mathrm{N}$ protein along with $\mathrm{M}$ protein mediates viral packaging and acts as a suppressor of antiviral RNA interference in SARS-CoV-2 (Mu et al., 2020). In addition to these structural proteins, eight more protein coding genes are present near $3^{\prime}$ terminus of the genome, known as accessory proteins: 3a, 3b, p6, 7a, 7b, 8a, 9b, and orf 14 (Wu A. et al., 2020). The 15 non-structural proteins (nsp1-10 and nsp12-16) are produced through the cleavage of polyproteins pplab and ppla expressed by the orflab and orfla gene constituting two thirds of the viral genome at its $5^{\prime}$ end (Mirza and Froeyen, 2020).

The first non-structural protein (nsp1), also christened as leader protein, has been reported to degrade host mRNA interacting with the $40 \mathrm{~S}$ ribosomal subunit in SARS-CoV. The virus expresses two proteases, 3-chymotrypsin-like protease
(3CLpro) and papain-like protease (PLpro), which are encoded by nsp5 and nsp 3, respectively (Kim et al., 2020). The 3CLpro, with a catalytic dyad defined by His 41 and Cys145, has 11 cleavage sites at the C-terminus (releasing Nsp4-Nsp16), whereas PLpro cuts at three other sites toward the N-terminus, mainly at 181-182, 818-819, and 2763-2764, generating a total of 15 nonstructural proteins (Ton et al., 2020; Wu A. et al., 2020). The nsp12 codes for RdRp and replicates RNA from RNA templates and nsp13 for helicase (Lung et al., 2020). The viral nascent RNA is capped at $5^{\prime}$ end and is catalyzed by the enzyme guanineN7-methyltransferase that is coded by nsp14. Additionally, the modification of this cap structure is executed by nsp16-encoded enzyme $2^{\prime}$-O-methyl transferase (Iftikhar et al., 2020). Though the receptor-binding domain in the $\mathrm{S}$ protein of SARS-CoV-2 is homologous with that of SARS-CoV, the amino acid varies at some key residues. A significant difference is the position of $\mathrm{RBD}$ in their respective down conformation. In the case of SARS-CoV, the RBD remains packed against the $\mathrm{N}$-terminal domain while it remains inclined closer to the central cavity of the trimer in SARS-CoV-2 (Wrapp et al., 2020). Irrespective of these variations, the amino acids at the interface residues of the SARS-CoV-2 RBD include Leu455, Phe456, Tyr473, and Gln493 in place of Tyr442, Leu443, Phe460, and Asn473, respectively, in SARS-CoV RBD (Yan et al., 2020).

\section{MECHANISM OF INFECTION IN HUMAN}

Though the receptor binding domain of SARS-CoV is similar to that of SARS-CoV-2, spike proteins of the latter have a strong affinity for the angiotensin-converting enzyme 2 receptor (ACE2) expressed abundantly on the human type II alveolar epithelial cells (AT2) of the lung, urothelial cells of the bladder, heart, and kidney, and enterocytes of intestinal cell surfaces (Sureda et al., 2020; Xu et al., 2020). SARS-CoV-2 can infect type I and type II pneumocytes as well as alveolar macrophages (Chu D.K.W. et al., 2020). The integral membrane protein ACE2, which accommodates metallopeptidase domain (PD) and collectrin-like domain (CLD), controls vasoconstriction and blood pressure, and plays a vital role in antiproliferation through the maturation of angiotensinII (Ang II) to angiotensin 1-7 [Ang(1-7)], serves as an antagonist of type 1 angiotensin receptor (AT2-R) (Tikellis and Thomas, 2012; Fandiño et al., 2018). Researchers have provided dismaying evidence of T-cell infection by SARS-CoV-2. It indicates the capability of the virus in binding receptors other than ACE2 as the expression of ACE2 receptor in T-cells is low (Wang Q. et al., 2020).

The 31st amino acid lysine present in ACE2 receptors of the host is reported to be identified by the glutamine amino acid of residue 394 in the receptor-binding domain (RBD) of SARSCoV-2. The 394 residue corresponds to residue 479 with a similar amino acid in SARS-CoV (Zhang H. et al., 2020). Structurally RBD of SARS-CoV-2 consists of a core region and a receptor binding motif (RBM). The end region of RBD that sets up contact with the ACE2 receptor is characterized by three variable loop regions, or contact regions: CR1, CR2, and CR3. Analysis of the RBD-ACE2 complex demonstrates a hydrogen bonding 
pattern between the CR3 loop region and ACE2 binding surface, whereas CR1 (N-terminal loop region) and CR2 (central region) strengthen binding through a hydrophobic interaction at the dimer interface (Wang Y. et al., 2020). Ingress into the host cell is mediated by the spike protein of the virus through the attachment of the S1 subunit on to the target cell surface. Research indicates that the C-terminal domain (CTD) of the S1 subunit in the spike protein of SARS-CoV-2 establishes more interactions with the hACE2 receptor, showing a binding affinity 10-15 times greater than SARS-CoV RBD (Wang Q. et al., 2020). Further, the priming of the $\mathrm{S}$ protein is essential for the fusion of the virus to human lung cells, facilitated by cellular proteases of the host (Letko et al., 2020). As a result, the cleavage of S protein at S1-S2 and S2' sites occur and the whole process is driven by the $\mathrm{S} 2$ subunit of the spike protein (Hoffmann et al., 2020). In the case of SARS-CoV2 , the cellular serine protease, TMPRSS2, expressed in ACE2 ${ }^{+}$ human pulmonary cells recognizes the "RRER" sequence at S1S2 site and acts as a priming agent of the S protein (Guo Y.-R. et al., 2020; Wang Q. et al., 2020). As mentioned earlier, due to the higher homology of SARS-CoV-2 with SARS-CoV, it would be speculated that they follow a similar entry pathway.

The fusion is followed by the uncoating and subsequent release of 30,000 base pairs of long +sRNA genomes, from which replicase genes (two thirds of the viral genome), encompassing ORF1a and ORF1b, are first translated into replicase polyprotein ppla and pplab (Cascella et al., 2020). Translation initiates at ORF1a, and ribosomal shifting ensures its uninterrupted expression up to ORF1b. The nsp3 and nsp5 present within ORF1a-ORF1b are responsible for autoproteolytic cleavage of large polyprotein as it encodes two viral proteases PLpro and Mpro (Gordon et al., 2020). Consequently, 16 non-structural proteins and $\mathrm{RdRp}$ are the products of this autoproteolytic activity. With the help of this Nsp12-encoded RdRp enzyme, a -sRNA is synthesized using the +sRNA as a template. Newly synthesized -sRNA serves as the template for the synthesis of the viral +sRNA genome. The nsp3, nsp4, and nsp6 encode several integral multi-spanning membrane proteins, playing an essential role in anchoring the replication-transcription complex (RTC) to the intracellular membranes. The other one third of the genome is discontinuously transcribed into a set of subgenomic mRNAs which are translated into viral structural proteins $\mathrm{S}, \mathrm{E}$, $\mathrm{M}$, and $\mathrm{N}$ proteins, as well as accessory proteins. Among these structural proteins, $\mathrm{N}$ protein is synthesized within the cytoplasm and encircles the genomic RNA to construct the virion, whereas the other three proteins, S, E, and $\mathrm{M}$ are translated and posttranslationally modified inside the endoplasmic reticulum (Fung and Liu, 2014). Further assembly and maturation of the virion occurs inside the ER-Golgi intermediate compartments (ERGIC) because, after folding, the assigned proteins ( $\mathrm{S}, \mathrm{M}$, and $\mathrm{E}$ proteins) are transported to ERGIC. Mature virus particles encapsidated inside the smooth vesicle are released upon fusion with the host cell plasma membrane. Previous findings suggest that during viral assembly, cell lines expressing TMPRSS2 protease tend to express spike proteins on the surface of their membrane, inducing attachment with the uninfected neighboring cells. Their fusion brings about the development of a large multinucleated cell, called syncytium (Matsuyama et al., 2020).

\section{AUTOPHAGY}

Autophagy is a self-cleaning biological process that obliterates the deleterious and malformed proteins and damaged organelles to regulate cellular homeostasis even under stress conditions. The unwanted cell components targeted for elimination are enclosed in a double membrane vesicle that ultimately fuses with lysosome for degradation of those enclosed components. Though the process is associated with cellular defense and survivability, it is also exploited by a few viruses to increase their infectious potency (Rozières et al., 2017). Such viruses slightly block this lysosomal degradation pathway and defend themselves by exploiting it to support their replication and virulence. Among them, $\mathrm{CoV}$ is reported to induce double-membrane vesicles' (DMV) formation in the parallelism of autophagosome that originates through the interaction of several proteins coded by autophagy related genes (ATG) (Prentice et al., 2004a). In a follow-up study, researchers demonstrated the colocalization of RTC with autophagic proteins LC3 (microtubule-associated protein light chain 3) and Atg12 at DMV (Prentice et al., 2004b). In general, this self-digesting process involves three steps- initiation, elongation, and fusion - which are regulated by 16 autophagy-related proteins (Atg proteins) and two ubiquitin-like conjugation systems. In brief, two complexes, one including class III phosphatidylinositol 3-kinase Vps34, Atg14, and the Atg6/Beclin1 complex while the second complex consists of serine/threonine kinase Atg1 associated with Atg8, LC3, GATE-16, and GABARAP in mammals, contribute together to generating phagophore (Maier and Britton, 2012). The expansion of phagophore and formation of autophagosome needs the recruitment of two-ubiquitin-like complexes, such as Atg12-Atg5-Atg-16 and Atg4B, Atg3, and Atg7, which facilitate the LC3 lipidation that is considered as a hallmark of autophagy. Complete formation of the autophagosome leads to the subsequent dissociation of the Atg16-Atg5-Atg12 complex and further fusion with lysosome is assisted by VPS15, UVRAG, VPS34, and Beclin 1 complex. Cottam et al. (2011) demonstrated the autophagy process to be induced by nsp6-encoded viral replicase protein in an infectious bronchitis virus (IBV) strain of CoV. Although CoV induces autophagy, several studies also indicate that it exhibits incomplete autophagy formation due to impaired fusion of autophagosomes with the lysosome, which is triggered by nsp3 coded PLpro in SARS-CoV, MERS$\mathrm{CoV}$, and membrane-associated papain like protease PLP2 (PLP2-TM) in HCoV-NL63 (Chen et al., 2014; Yang and Shen, 2020). Association of PLP2-TM with LC3 and Beclin1 further enhances the interaction between Beclin1 with STING, consequently suppressing the expression of antiviral interferons. Adaptation of the virus to this incomplete autophagy process prevents degradation of their components, thus blocking them from the innate antiviral immunity. Schneider et al. (2012) signifies that SARS-CoV replication is not hampered by the downregulation of ATG7 or ATG5, key autophagy proteins also involved in autophagosome biogenesis. Analysis of data from various studies conclude that the inhibition of autophagy does not impair the $\mathrm{CoV}$ replication and infection process, but rather that activation of autophagy and its subsequent 
maturation might lead to the destruction of viral components (Carmona-Gutierrez et al., 2020). Therefore, it can be assumed that the activation of the autophagy process might be an impactful step in inhibiting viral replication, as both SARS-CoV and SARS-CoV-2 share somewhat similar infection processes, like the involvement of host cell receptor ACE2.

\section{ENDOPLASMIC RETICULUM STRESS AND APOPTOSIS}

Various analyses have concluded that $\mathrm{CoV}$ infection (not specifically 2019-nCoV) is directly associated with the endoplasmic reticulum stress induction in host cells due to three specific viral mechanisms: DMV formation, posttranslational modification of viral structural proteins, and lipid depletion during the exocytosis of virions (Fung and Liu, 2014). Snijder et al. (2006) demonstrated the co-localization of SARS$\mathrm{CoV}$ non-structural proteins along with an ER marker, protein disulphide isomerase (PDI). Two endosome cargos, mannosidase $\alpha$-like 1 (EDEM1) and osteosarcoma amplified 9 (OS-9), have been shown to colocalize with the RTCs during mouse hepatitis virus (MHV) infection, as observed by Reggiori et al. (2010). After a couple of studies, a model has been proposed regarding the sequestration of COPII-independent endosomes exported from ER by CoV for its DMV formation, suggesting ER as the origin of DMVs. Coronavirus replication and assembly lead to great ER-stress, as the viral trimeric spike glycoprotein undergoes glycosylation at the S2 domain, maturation, and further assembly inside ER, mediated by calnexin-like chaperons (Fukushi et al., 2012). According to $\mathrm{Nal}$ et al. (2005), not only the $\mathrm{S}$ protein but also the $\mathrm{M}$ protein of $\beta$-coronavirus undergoes $\mathrm{O}$-linked glycosylation inside ER. As mentioned before, ERGIC is the site of virion assembly; therefore, budding or exocytosis of mature virions causes the cutback of lipid from ER. The translation of viral proteins inside ER leads to the accumulation of unfolded and misfolded proteins inside ER lumen that overwhelms ER capacity. For upholding the stability of ER during CoV infection, the signaling pathways, called unfolded protein response (UPR), are activated by interacting with its three branches: protein kinase RNA-activated (PKR)-like ER protein kinase (PERK), activating transcription factor 6 (ATF6), and inositol-requiring enzyme 1 (IRE1). Earlier studies have shown phosphorylated PERK, PKR, and eIF $2 \alpha$ in SARS-CoV infected cells and suggested the activation of PKR by its infection might lead to apoptosis (Krähling et al., 2009). Moreover, Deng et al. (2017) has pointed out the possibility of PKR suppression is due to the action of nsp15-coded endonuclease. Shi et al. (2019) also indicated that ORF-8b expression induces the upregulation of CHOP and UPR proteins, which together promotes cell death by forming protein aggregates relying on its amino acid valine at 77 positions. Although the ORF-8b of SARS-CoV has less homology with that of SARS-CoV-2, the maturation of viral proteins occurring inside the ER might increase the workload, causing ER stress and subsequent apoptosis (Fung et al., 2020). Furthermore, the PERK and IRE1 signaling pathways are common to both the cellular events of ER stress and autophagy, which justify that these processes are inter-connected via the UPR system (Shojaei et al., 2020). The accumulated unfolded and misfolded proteins subsequently increase ER stress and, to combat it, the cytosolic ubiquitin-proteasomes level increases (Boga and Coto-Montes, 2020). Before apoptosis, cells activate autophagy to degrade the protein aggregates for their survivability (Yorimitsu et al., 2006). But the induction of incomplete autophagy upon SARS-CoV-2 infection generates DMV that in turn supports viral replication. Activation of autophagy by PERK and IRE1 branches are interconnected where activated DNA damage-inducible transcript 3 (DDIT3), also known as CCAAT/enhancer-binding protein homologous protein (CHOP), facilitates the dissociation of beclin1 (BECN1) from B-cell lymphoma 2 (BCL2). The activation of CHOP expression is induced via activating transcription factor (ATF4) stimulation by PERK. Similarly, evidence also suggests that the IRE1 pathway helps to trigger the phosphorylation of BCL2 through the mitogen-activated protein kinase (MAPK/JNK) pathway, which in turn enables beclin 1 (BECN1) to induce autophagy (Kapuy et al., 2014). Besides this, ER stress mediated the downregulation of the cell growth regulator mechanistic target of rapamycin (MTOR), which activates autophagy by inhibiting the serine/threonine-protein kinase $(\mathrm{AKT})$ in the AKT-MTOR signaling pathway regulated by the ATF6 branch; the whole process of the autophagy/UPR pathway and their interconnections are represented in Figure $\mathbf{1}$ (Rashid et al., 2015; Bello-Perez et al., 2020; Sureda et al., 2020).

\section{INFLAMMASOME}

The inflammasome in multiprotein complexes is accountable for the activation of inflammatory reactions, having a role in promoting antiviral innate immune response and the spreading of viral infection. Among all inflammasomes, the NOD-like receptor (NLR) family pyrin domain-containing 3 (NLRP3) inflammasome is mostly involved in inflammation, and pyroptosis are ensured due to viral infections. As reports suggest, viruses exploit this phenomenon to escalate their infection rapidly and to evade the host's immune system by facilitating the expression of IL- $1 \beta$ through the activation of NLRP3 inflammasome. The ion-redistribution, mitochondrial damage, and lysosomal disruption induced by the viroporins (ORF3a, ORF8b, and E protein) of SARS-CoV account for caspase-1 activation accelerating NLRP3 inflammasome stimulation (Shah, 2020). SARS-CoV E protein and ORF-3a promote NF- $\kappa$ B mediated pro-IL-1 $\beta$ gene transcription, IL- $1 \beta$ secretion, and NLRP3 expression (Freundt et al., 2010; NietoTorres et al., 2015). Recent evidence has pointed out the ORF3a-mediated activation of NLPR3 inflammasome in SARSCoV-1 infected cells promotes TRAF3-dependent facilitation of polyubiquitination of apoptosis-associated speck-like protein (ASC). The interaction of trio-ORF3a with TRAF3 along with ASC leads to ASC speck formation (Siu et al., 2019). ASC, carrying the inactive procaspase-1 along with the caspase activation and recruitment domain, constitutes the adapter component of NLRP3. As per the pathogenesis of SARS$\mathrm{CoV}-2$, the lung inflammation indicates the interaction of 


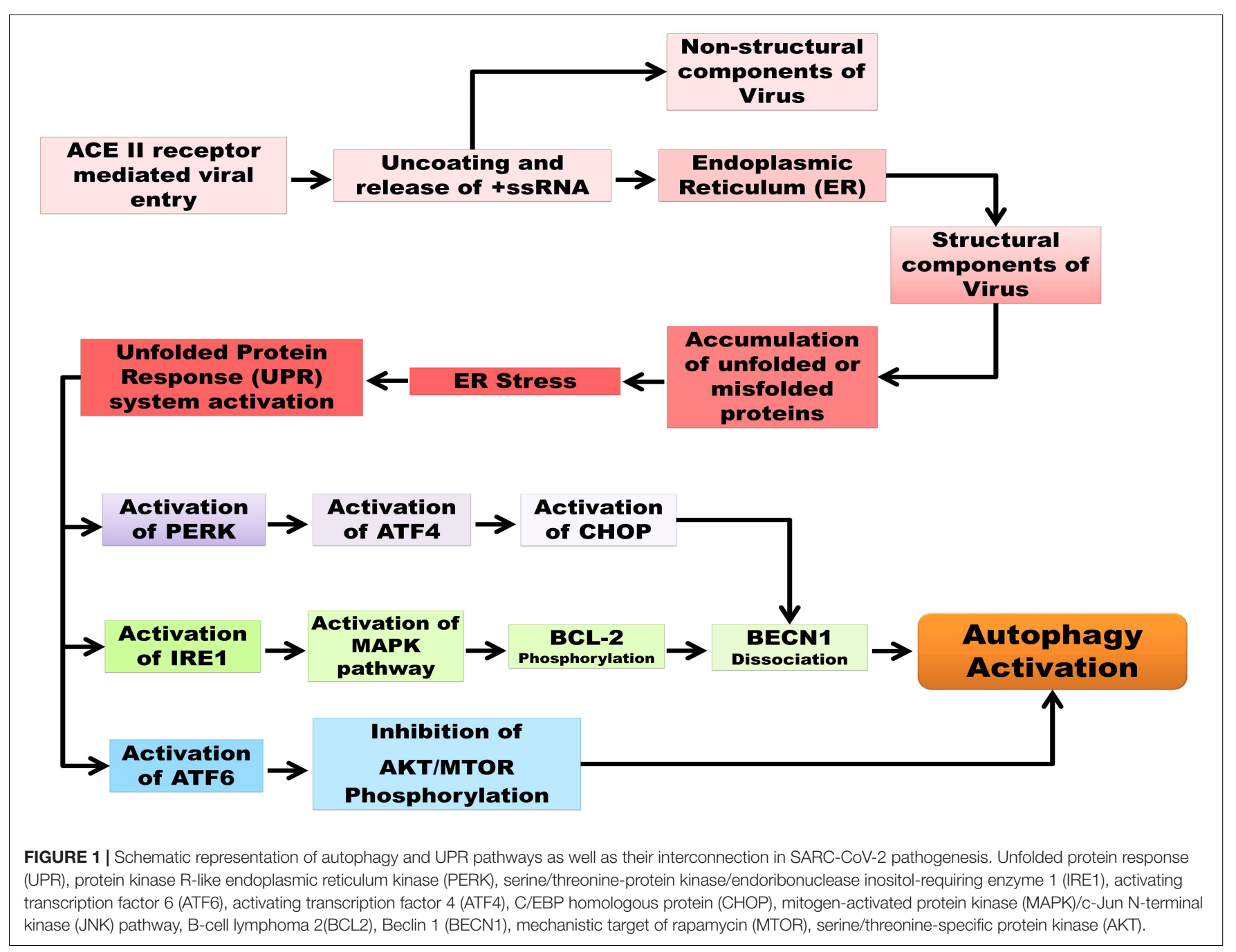

the virus with toll-like receptor (TLR), which promotes the expression of pro-IL-1 $\beta$ and the release of IL-1 $\beta$. The secretion of inflammatory cytokines further triggers the expression of other downstream effectors involved in inflammation, including tumor necrosis factor (TNF), interleukin 6 (IL6), leukotrienes, and prostaglandins (Mangan et al., 2018). Activation of NLRP3 inflammasome and caspase-1 induces expression of non-canonical caspases, including caspase-4, caspase-5, and caspase-11, which promote pore formation on cell membranes by causing the release of gasderminD. Consequently, a massive influx of water and $\mathrm{Na}^{+}$ions result in excessive swelling of cells, leading to cell membrane rupture or pyroptosis (Yap et al., 2020). However, SARS-CoV $\mathrm{E}$ protein shares a $95 \%$ homology with its counterparts in SARS-CoV-2, whereas ORF3a has only $72 \%$, so it can be extrapolated that the E protein of SARS-CoV-2 might have a role in the activation of inflammasome (Fung et al., 2020). Considering the role of E protein in the activation of NLRP3 inflammasome, it can be affirmed that targeting the viral $\mathrm{E}$ protein would extricate the host cell from the detrimental effects of the inflammasome.

\section{IMMUNE RESPONSE OF SARS-CoV-2}

Invasion of a virus surges both innate and adaptive immunity. Further destruction of virus-infected cells elicits local macrophages and monocytes to migrate and release cytokines that trigger $\mathrm{T}$ and $\mathrm{B}$ cells. Viral infection causes the release of diverse pathogen-associated molecular patterns, such as viral RNAs, proteins, and ASC oligomers, which are recognized by toll-like receptors (TLRs) and RIG-like receptors (RLRs), a kind of pattern-recognition receptors (PRRs) that are located in cytosolic or endosomal compartments (Park and Iwasaki, 2020). Activation of alveolar macrophages and lymphocytes trigger inflammation as well as the release of pro-inflammatory cytokines and chemokines in an increased level (Zhong et al., 2020). Reports suggest that this cytokine storm, including IFN $\gamma$-induced protein-10 (IP10), macrophage chemoattractant protein1 (MCP1), IL-6, tumor necrosis factor $\alpha$ (TNF $\alpha)$, granulocyte colony-stimulating factor (GCSF), and macrophage inflammatory protein $1 \alpha(\mathrm{MIP} 1 \alpha)$, are associated with severe clinical outcomes in COVID-19 patients (Huang et al., 2020; Tay et al., 2020). Higher concentrations of cytokines and 
pro-inflammatory cytokines cause acute respiratory distress syndrome (ARDS), which is a major factor of death in cases of the recent coronavirus infection. To evade the innate immune system, the virus has developed diverse strategies such as avoiding PAMPs recognition by PRRs and the inhibition of interferon production and interferon-signaling pathways. Interferon, being a part of the innate immune system, exhibits antiviral activity (Noh, 2020). Viral infection induces both type 1 and type III interferons that further execute a plethora of effector mechanisms against viruses. In the case of viral infection, detection of virus-associated PAMPs by intracellular PRRs subsequently activates transcription factors, mainly interferon regulator factors (IRFs) and nuclear factor $\kappa \mathrm{B}(\mathrm{NF}-\kappa \mathrm{B})$. The activation of IRFs evoke an antiviral response by enhancing the expression of type I and type III interferons, as well as IFNstimulated genes (ISGs). Type 1 IFN interaction with its receptor initiates a signaling cascade through phosphorylation and subsequent activation of transcription factors. The transcription factors are signal transducer and activators of transcription 1 (STAT1) and STAT2 which, along with IRF9, actuate ISGs' expression via IFN-stimulating gene factor 3 (ISGF3) intermediate complex formation (Blanco-Melo et al., 2020). As a result, virus replication is interrupted and viral resistance is developed, ensuring the induction of the adaptive immune system. The $5^{\prime}$ capping mechanism performed by nsp 14 and nsp16 in SARS-CoV-2 enables viral RNA to mimic host RNA, that in turn can prevent its detection by RLR receptors. SARS-CoV-1 infection promotes type 1, type II, and type III IFNs' production while SARS-CoV-2 is not reported to induce their expression, which leads to insignificant activation of the innate immune system. An asymptomatic phase of COVID-19 in patients could arise due to this low activation of the immune system ( $\mathrm{Chu} \mathrm{H}$. et al., 2020). In SARS-CoV-1, ORF3b, ORF6, nsp1, nsp3, and two structural proteins, $\mathrm{N}$ and $\mathrm{M}$, act as antagonists to IFN signaling (Totura and Baric, 2012). As per the sequence analysis study, SARS-CoV-2 has a high sequence homology with nsp1 and other structural proteins of SARS-CoV-1 but differs greatly with respect to the other above-mentioned genomic regions. Recent studies suggest that the 22 amino acid long ORF-3b protein of SARS-CoV-2 can significantly inhibit IFN activation (Konno et al., 2020) however, SARS-CoV-2 susceptibility to type 1 interferon is still under scrutiny.

\section{GENETICS AND EPIGENETICS}

Pathogenesis of a virus can be ascertained through the impact of diverse cytopathic effects and through genetic and epigenetic changes. Human coronaviruses, including HCoV-229E, NL63, $\mathrm{HCoV}-\mathrm{OC} 43$, and SARS-CoV, upon infection are reported to bring out transcriptome changes in the host cell. In the case of SARS-CoV, microarray analysis reveals that around 164 genes are altered; out of these, 17 are downregulated, while 49 genes are known to be upregulated. Among the upregulated genes, about 11 genes, like proapoptotic, 4 genes- phospholipid scramblase 1 (PLSCR1), thrombospondin 1 (THBS1), early growth response 1 gene (EGR1), and plasminogen activator inhibitor 1 (PAI1/SERPINE1), are associated with the procoagulant pathway. In addition, 32 genes, including transforming growth factor $\beta 2$ (TGF- $\beta 2$ ), IL-8, chemokines CXCL-1, -2, -3, -5, -6, -10, tumor necrosis factor $\alpha$ (TNF- $\alpha)$, and many more, are also stimulated by inflammation and immune response (Tang et al., 2009). Thus, $\mathrm{CoV}$ infection conciliates massive genetic changes in the host cell. Epigenetics, the interface between the environment and the genome, deals with alterations in gene expression patterns through various modifications in a gene, such as DNA methylation, chromatin remodeling, and histone modifications, without altering the genome sequences. A broad range of studies have explained the virus-mediated host's epigenetic modulation that supports their replication and pathogenesis by evading the host's antiviral immune system. Many recent studies demonstrate that $\mathrm{CoV}$ enhances its virulence potency by manipulating IFNstimulated gene (ISG) histone modification, resulting in the delayed expression of ISG effectors validated in both SARSCoV and MERS-CoV (Schafer and Baric, 2017). The molecular mechanism behind the upregulation of several NF- $\mathrm{B}$ target genes in SARS-CoV-infected cells suggests the underlying posttranslational modification of several proteins to phosphorylation, ubiquitylation, and subsequent proteasomal degradation of the

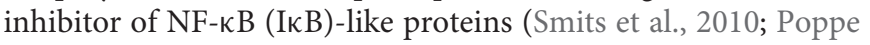
et al., 2017). However, these genetic and epigenetic modifications of the host infected with SARS-CoV-2 have not yet been properly investigated. Currently available research is mostly associated with epigenetic modifications of ACE2 receptors. Available research evidence suggests that oxidative stress induced by SARS-CoV-2 infection leads to the overexpression of ACE2 due to its hypomethylation on the X chromosome (Pruimboom, 2020). Commonly, the lowest expression of ACE2 receptor in leukocytes and neurons is associated with its hypermethylated state, while in lung epithelial cells, the gene is hypomethylated (Corley and Ndhlovu, 2020). In short, these findings describe the role of epigenetics in age-related fatality of COVID-19, whereas ACE2 hypomethylation demonstrates a direct proportionality with aging as well as greater viremia. Therefore, present investigations are more focused on targeting the epigenetic modifications of host's ACE2 receptors (Mueller et al., 2020; Sawalha et al., 2020).

\section{AVAILABLE DETECTION AND INHIBITION STRATEGY OF SARS-CoV-2}

Early and rapid diagnostic techniques are imperative in the management of the SARS-CoV-2 outbreak. But presently available diagnostic kits, for example, PCR based techniques, serum-based tests, and the most recently developed non-invasive tests, take a detection time of around 2-8 h, 15-60 min, and $\leq 15 \mathrm{~min}$, respectively (Carter et al., 2020). The viral molecular components, specifically ORF $1 \mathrm{ab}$ and nucleocapsid gene $\mathrm{N}$, ORF1b-nsp 14, S gene, and RdRP gene, are currently being targeted for the detection of SARS-CoV-2 infection through the RT-PCR methods. Presently, serum-based diagnostic tests are preferred overt RT-PCR based diagnostic tests due to their shorter time frame of detection (Table 1A). 
TABLE 1A | List of different diagnostic test available for detection of SARS-CoV-2.

\begin{tabular}{|c|c|c|c|c|c|}
\hline SI. No. & Name & Developing organization & Mode of detection & Mechanism of detection & References \\
\hline 1 & $\begin{array}{l}\text { New coronavirus nucleic } \\
\text { acid determination kit }\end{array}$ & $\begin{array}{l}\text { Chinese National Institute } \\
\text { for Viral Disease Control } \\
\text { and Prevention, China }\end{array}$ & $\begin{array}{l}\text { Real-time fluorescence } \\
\text { RT-PCR method }\end{array}$ & $\begin{array}{l}\text { Detecting the novel coronavirus } \\
\text { with RT-PCR using primers } \\
\text { against ORF } 1 \mathrm{ab} \text { and } \\
\text { nucleocapsid gene } \mathrm{N} \text {, and } \\
\text { fluorescent probes }\end{array}$ & $\begin{array}{l}\text { CDCP, 2020b; } \\
\text { Sheridan, 2020; WHO, } \\
\text { 2020a }\end{array}$ \\
\hline 3 & $\begin{array}{l}\text { Real-time reverse } \\
\text { transcriptase PCR assays }\end{array}$ & $\begin{array}{l}\text { University of Hong Kong, } \\
\text { Hong Kong }\end{array}$ & Real-time RT-PCR method & $\begin{array}{l}\text { Two single-step quantitative } \\
\text { real time RT-PCR assays using } \\
\text { primers against ORF1b-nsp } 14 \\
\text { and N genes }\end{array}$ & $\begin{array}{l}\text { Sheridan, 2020; } \\
\text { Udugama et al., 2020; } \\
\text { WHO, 2020b }\end{array}$ \\
\hline 5 & $\begin{array}{l}\text { RealStar }{ }^{\circledR} \text { SARS-CoV-2 } \\
\text { RT-PCR Kit } 1.0\end{array}$ & $\begin{array}{l}\text { Altona Diagnostics, } \\
\text { Germany }\end{array}$ & Real-time RT-PCR method & $\begin{array}{l}\text { This method targets the } \\
\text { detection of E gene in B- } \beta \text { CoV } \\
\text { RNA and } S \text { gene in } \\
\text { SARS-CoV-2 RNA using } \\
\text { specific fluorescent probes, } \\
\text { which enables the parallel } \\
\text { detection of B- } \beta \text { CoV specific } \\
\text { RNA and SARS-CoV- } 2 \text { specific } \\
\text { RNA }\end{array}$ & $\begin{array}{l}\text { Altona, 2020; Sheridan, } \\
2020\end{array}$ \\
\hline 6 & $\begin{array}{l}2019 \text { novel coronavirus } \\
\text { (2019-nCoV) by real-time } \\
\text { RT-PCR }\end{array}$ & $\begin{array}{l}\text { Charité - } \\
\text { Universitätsmedizin, } \\
\text { Germany }\end{array}$ & Real-time RT-PCR method & $\begin{array}{l}\text { This method targets the } \\
\text { amplification of } \\
\text { RNA-dependent RNA } \\
\text { polymerase (RdRP), E and N } \\
\text { genes in viral RNA and their } \\
\text { detection with specific } \\
\text { fluorescent probes using the } \\
\text { real time RT-PCR workflow }\end{array}$ & $\begin{array}{l}\text { Corman et al., 2020; } \\
\text { Sheridan, 2020; } \\
\text { Udugama et al., } 2020\end{array}$ \\
\hline 8 & $\begin{array}{l}\text { Novel Coronavirus } \\
2019 \text {-nCoV nucleic acid } \\
\text { detection kit (cPAS, } \\
\text { combinatorial probe-anchor } \\
\text { synthesis sequencing } \\
\text { method) }\end{array}$ & BGI Group, China & $\begin{array}{l}\text { Metagenomics and } \\
\text { RT-PCR method }\end{array}$ & $\begin{array}{l}\text { This metagenomics sequencing } \\
\text { kit is based on combinatorial } \\
\text { Probe Anchor Synthesis. It is } \\
\text { able to detect both known and } \\
\text { novel microorganisms, enabling } \\
\text { monitoring of evolution during } \\
\text { transmission }\end{array}$ & $\begin{array}{l}\text { BGI, 2020a; Pang } \\
\text { et al., 2020; Sheridan, } \\
2020\end{array}$ \\
\hline 9 & $\begin{array}{l}\text { TaqMan 2019-nCoV Assay } \\
\text { Kit }\end{array}$ & $\begin{array}{l}\text { Thermo Fisher Scientific, } \\
\text { United States }\end{array}$ & Real-time RT-PCR method & $\begin{array}{l}\text { This method employs the } \\
\text { amplification of specific region } \\
\text { of ORF1ab, } \mathrm{S} \text { and } \mathrm{N} \text { genes in } \\
\text { viral RNA followed by their } \\
\text { detection using fluorescent } \\
\text { probes. Human RNase } \mathrm{P} \text { was } \\
\text { used as positive control. It runs } \\
\text { on Applied Biosystems } 7500 \\
\text { RT-PCR system }\end{array}$ & $\begin{array}{l}\text { Sheridan, 2020; } \\
\text { ThermoFisher, } 2020\end{array}$ \\
\hline 10 & $\begin{array}{l}\text { 2019-nCoV nucleic acid } \\
\text { detection kit }\end{array}$ & $\begin{array}{l}\text { National Institute of } \\
\text { Infectious Disease, Japan }\end{array}$ & Real-time RT-PCR method & $\begin{array}{l}\text { This method involves the } \\
\text { amplification of specific region } \\
\text { of } \mathrm{N} \text { gene in viral RNA followed } \\
\text { by their detection using } \\
\text { fluorescent probes }\end{array}$ & $\begin{array}{l}\text { Nao et al., 2020; } \\
\text { Sheridan, 2020; } \\
\text { Udugama et al., } 2020\end{array}$ \\
\hline
\end{tabular}


TABLE 1A | Continued

\begin{tabular}{|c|c|c|c|c|c|}
\hline SI. No. & Name & Developing organization & Mode of detection & Mechanism of detection & References \\
\hline 12 & $\begin{array}{l}\text { On-site rapid molecular } \\
\text { diagnostic system based } \\
\text { on Shenzhen Shineway } \\
\text { Technology }\end{array}$ & $\begin{array}{l}\text { Hong Kong University of } \\
\text { Science and Technology, } \\
\text { Hong Kong }\end{array}$ & Real-time RT-PCR method & $\begin{array}{l}\text { Integrated microfluidic PCR test } \\
\text { employing silicon-based } \\
\text { micro-heater module for rapid } \\
\text { heating and processing of test } \\
\text { samples }\end{array}$ & Sheridan, 2020 \\
\hline 13 & $\begin{array}{l}\text { COVID-19 genesig } \\
\text { Real-Time PCR assay }\end{array}$ & $\begin{array}{l}\text { Primerdesign Ltd., } \\
\text { United Kingdom }\end{array}$ & Real-time RT-PCR method & $\begin{array}{l}\text { Specific amplification of a region } \\
\text { of ORF } 1 \text { ab gene in viral RNA } \\
\text { followed by their detection using } \\
\text { fluorescent probes }\end{array}$ & $\begin{array}{l}\text { Primerdesign, 2020; } \\
\text { Sheridan, } 2020\end{array}$ \\
\hline 14 & $\begin{array}{l}\text { QIAstat-Dx Respiratory } \\
\text { 2019-nCoV Panel }\end{array}$ & Qiagen, Germany & Real-time RT-PCR method & $\begin{array}{l}\text { Integrated sample prep and } \\
\text { RT-PCR detection of } 21 \\
\text { respiratory pathogens including } \\
\text { 2019-nCoV; the result is analyzed } \\
\text { in desktop QIAstat-Dx Analyzer }\end{array}$ & Sheridan, 2020 \\
\hline 16 & VereCoV ${ }^{\mathrm{TM}}$ Detection Kit & $\begin{array}{l}\text { Veredus Laboratories Pte } \\
\text { Ltd., Singapore and } \\
\text { Singapore Institute for } \\
\text { Health Innovation, } \\
\text { Singapore }\end{array}$ & Real-time RT-PCR method & $\begin{array}{l}\text { It integrates an ultra-fast } \\
\text { miniaturized PCR reactor for the } \\
\text { amplification of target gene and a } \\
\text { customized microarray to } \\
\text { qualitatively detect 2019-nCov } \\
\text { virus }\end{array}$ & $\begin{array}{l}\text { Sheridan, 2020; } \\
\text { Veredus, } 2020\end{array}$ \\
\hline 17 & $\begin{array}{l}\text { Tib-Molbiol's 2019-nCoV } \\
\text { Real-time RT-PCR kit }\end{array}$ & $\begin{array}{l}\text { TIB Molbiol, Germany also } \\
\text { via Roche Diagnostics, } \\
\text { Switzerland }\end{array}$ & Real-time RT-PCR method & $\begin{array}{l}\text { Specific amplification of RdRP or } \\
\text { E or } N \text { genes in viral RNA, } \\
\text { followed by their detection using } \\
\text { fluorescent probes }\end{array}$ & $\begin{array}{l}\text { Roche, 2020; Sheridan, } \\
2020\end{array}$ \\
\hline \multicolumn{6}{|c|}{ (B) Serum-based test } \\
\hline 1 & $\begin{array}{l}\text { anti-SARSr-CoV IgG and } \\
\text { IgM ELISA kits }\end{array}$ & $\begin{array}{l}\text { Chinese Academy of } \\
\text { Sciences, China }\end{array}$ & $\begin{array}{l}\text { Enzyme-Linked } \\
\text { Immunosorbant Assay } \\
\text { (ELISA) }\end{array}$ & $\begin{array}{l}\text { Detection of antibodies in human } \\
\text { serum produced against } \\
\text { SARS-CoV-2 Rp3 nucleocapsid } \\
\text { protein by ELISA }\end{array}$ & $\begin{array}{l}\text { Udugama et al., 2020; } \\
\text { Zhang W. et al., } 2020\end{array}$ \\
\hline 2 & $\begin{array}{l}\text { qSARS-CoV-2 lgG/lgM } \\
\text { Rapid Test }\end{array}$ & Cellex Inc., United States & ELISA & $\begin{array}{l}\text { Qualitative detection of IgM and } \\
\text { IgG antibodies against } \\
\text { SARSCoV-2 in serum, plasma or } \\
\text { venipuncture whole blood from } \\
\text { individuals suspected of } \\
\text { COVID-19 }\end{array}$ & Cellex, 2020 \\
\hline 3 & $\begin{array}{l}\text { Diagnostic Kit for lgM/lgG } \\
\text { Antibody to Coronavirus } \\
\text { (SARS-CoV-2) }\end{array}$ & $\begin{array}{l}\text { Zhuhai Livzon Diagnostics } \\
\text { Inc., China }\end{array}$ & ELISA & $\begin{array}{l}\text { Detection of IgM and IgG } \\
\text { antibodies against SARSCoV-2 in } \\
\text { serum, plasma or venous blood } \\
\text { from individuals suspected of } \\
\text { COVID-19 }\end{array}$ & $\begin{array}{l}\text { Udugama et al., 2020; } \\
\text { Xiang et al., } 2020\end{array}$ \\
\hline 4 & $\begin{array}{l}\text { Novel coronavirus } \lg G / \lg M \\
\text { antibody GICA kits }\end{array}$ & $\begin{array}{l}\text { Zhuhai Livzon Diagnostics } \\
\text { Inc., China }\end{array}$ & $\begin{array}{l}\text { Colloidal Gold } \\
\text { Immunochromatographic } \\
\text { Assay (GICA) }\end{array}$ & $\begin{array}{l}\text { Detection of IgM and IgG } \\
\text { antibodies against SARSCoV-2 in } \\
\text { serum, plasma, or venous blood } \\
\text { using gold-labeled pad from } \\
\text { individuals suspected of } \\
\text { COVID-19 }\end{array}$ & $\begin{array}{l}\text { Udugama et al., 2020; } \\
\text { Xiang et al., } 2020\end{array}$ \\
\hline
\end{tabular}


TABLE 1A | Continued

\begin{tabular}{|c|c|c|c|c|c|}
\hline SI. No. & Name & Developing organization & Mode of detection & Mechanism of detection & References \\
\hline 5 & $\begin{array}{l}\text { Peptide-based luminescent } \\
\text { immunoassay to detect lgG } \\
\text { and lgM }\end{array}$ & $\begin{array}{l}\text { Key Laboratory of } \\
\text { Molecular Biology on } \\
\text { Infectious Diseases, } \\
\text { Chongqing Medical } \\
\text { University, China }\end{array}$ & $\begin{array}{l}\text { Peptide based luminescent } \\
\text { immunoassay }\end{array}$ & $\begin{array}{l}\text { Detection of } 2019 \text {-nCov IgG and } \\
\text { IgM antibodies using synthetic } \\
\text { peptide antigens from the } \\
\text { orf1a/b, spike (S), and } \\
\text { nucleocapsid }(\mathrm{N}) \text { proteins as the } \\
\text { immunosorbent }\end{array}$ & $\begin{array}{l}\text { Cai X.-F. et al., 2020; } \\
\text { Udugama et al., } 2020\end{array}$ \\
\hline 6 & $\begin{array}{l}\text { COVID-19 IgM-IgG Dual } \\
\text { Antibody Rapid Test }\end{array}$ & $\begin{array}{l}\text { BioMedomics, Inc., } \\
\text { United States }\end{array}$ & ELISA & $\begin{array}{l}\text { Qualitative detection of IgM and } \\
\text { IgG antibodies against } \\
\text { SARS-CoV-2 in serum, plasma, } \\
\text { or venous blood from individuals } \\
\text { suspected of COVID-19 }\end{array}$ & BioMedomics, 2020 \\
\hline \multicolumn{6}{|c|}{ (C) Non-invasive test } \\
\hline 1 & $\begin{array}{l}\text { Low-Frequency Raman } \\
\text { Spectroscopy as a } \\
\text { Diagnostic Tool for } \\
\text { COVID-19 }\end{array}$ & Bar-Ilan University, Israel & $\begin{array}{l}\text { Low-Frequency Raman } \\
\text { spectroscopy }\end{array}$ & $\begin{array}{l}\text { The distinct nanostructure of } \\
\text { SARS-CoV-2 will give a unique } \\
\text { spectral signature under low } \\
\text { frequency Raman spectroscopy, } \\
\text { which will not be decay by laser } \\
\text { excitation }\end{array}$ & Jacobi et al., 2020 \\
\hline
\end{tabular}

Serum-based diagnostic tests are generally antibody-targeted tools against either the whole SARS-CoV-2, or against Rp3 nucleocapsid $(\mathrm{N})$ proteins, synthetic peptide antigens from the orfla/b, S, and $\mathrm{N}$ proteins. Additionally, the non-invasive diagnostic test through which the viral infection can be quickly detected within 15 min has significantly gained attraction in the present situation and has been credited as a novel piece of work (Table 1A). Though these methods are effective in viral detection, some of which are even considered as gold standard for viral detection, like RT-PCR based techniques, these methods still possess their own pros and cons (Table 1B). However, the non-invasive methods of detection might be further enhanced with high accuracy by augmentation with nanotechnology (Kerry et al., 2019). There has been some evidence suggesting the efficacy of viral detection through nano-based viral sensors, which needs further improvement(s). But the potential associated with the application of nano-based materials is beyond the comprehension of our imagination (Kerry et al., 2018; Islam et al., 2019; Saylan et al., 2019).

Researchers have been racing against time to understand this new virus and the etiology of this disease to unveil feasible treatment regimens and discover novel therapeutic interventions (Liu et al., 2020). There are no novel committed anti-viral therapeutics against COVID-19, but rather previously used antiviral strategies involving small molecules and biologics targeting complex molecular interactions are applied to control/check the infection and, in the meantime, scientists are tirelessly working to discover more effective methods. Some of the currently used conventional antiviral drugs are listed in Table 2. These drugs are conventionally used for treatment against other deadly viral or protozoal infections, such as HIV or AIDS, influenza virus, Ebola virus, respiratory syncytial virus (RSV), hepatitis C and B virus, RNA viruses like flaviviruses, togaviruses, bunyaviruses, arenaviruses, paramyxoviruses, coronaviruses, filoviruses, orthomyxoviruses, and picornaviruses, and helminthic and protozoal parasites (Table 2). Each of these drugs has been found to exert a certain degree of antiviral impact in SARS-CoV-2 infection. It has also been found that combinations of these antiviral drugs are effective for the treatment of COVID-19 patients (Stebbing et al., 2020).

The main reasons behind the effectiveness of these drugs are their ability to transverse across the cellular membrane. Further, this impact is complemented by their other determined functions, such as Janus kinase (JKA) inhibition (Richardson et al., 2020), viral protease inhibition (Harrison, 2020; Shamsi et al., 2020), viral RNA polymerase inhibition (Elfiky, 2020), nucleoside inhibition (Khalili et al., 2020), cell membrane endocytosis inhibition (Wong et al., 2020), the inhibition of multidrug and toxin extrusion protein (MATE) 1-mediated metformin transport (McCreary and Pogue, 2020), and DNA synthesis inhibition (Sallard et al., 2020). The currently available drugs have a certain promising effect against SARS-CoV-2, but also present complications for the host, except for Galidesivir (Crasto, 2020; $\mathrm{NIH}, 2020)$. Therefore, the approach should be taken to either eliminate or neutralize the adverse impacts of these drugs or to amalgamate other multipotential technological adversaries, like nanotechnology (Islam et al., 2019; Saylan et al., 2019).

\section{NANOTECHNOLOGICAL ADVANCEMENT IN DETECTION OF VIRAL INFECTION}

Transdisciplinary and progressive evaluation of nanotechnology in viral detection have transformed conventional diagnostic approaches by converging electronics and surface science to areas of biomedical sciences (Vaculovicova et al., 2017). Exploiting nanomaterials for engineering nano-based-biosensors could facilitate early detection, even with a low volume of the sample (Campos et al., 2020). Nanosensors are commonly equipped with a receptor, a transducer, and a detector consisting of a digital output (Saylan et al., 2018). The target molecule comes into contact with the receptor (Goode et al., 2015) and the biological detection component identifies the molecule via 
TABLE 1B | Merits and demerits of different diagnostic methods used for SARS-CoV-2 detection.

\begin{tabular}{|c|c|c|c|}
\hline SI. No. & Detection methods & Merits & Demerits \\
\hline \multirow[t]{4}{*}{1} & RT-PCR method & $\begin{array}{l}\text { It is the most frequently used gold } \\
\text { standard frontline test for } \\
\text { COVID-19 that directly detects the } \\
\text { presence of viral RNA }\end{array}$ & $\begin{array}{l}\text { RT-PCR requires prior sequence data } \\
\text { of the specific target gene of interest }\end{array}$ \\
\hline & & $\begin{array}{l}\text { It is fairly quick, sensitive and } \\
\text { reliable, capable of producing } \\
\text { results in } 4-5 \mathrm{~h}\end{array}$ & $\begin{array}{l}\text { Difficulties in RNA isolation from } \\
\text { samples like sputum or environmental } \\
\text { samples may give false-negative results } \\
\text { especially when target particles are low } \\
\text { in number }\end{array}$ \\
\hline & & $\begin{array}{l}\text { This technology is widely available } \\
\text { and very common in research and } \\
\text { medicine, and already in place to } \\
\text { test for COVID-19 }\end{array}$ & $\begin{array}{l}\text { Since this method detects current } \\
\text { infection so there is a possibility to miss } \\
\text { patients who have cleared the virus. } \\
\text { Unable to monitor the progress of the } \\
\text { disease stages so failed to perform } \\
\text { broad identification of past infection } \\
\text { and immunity }\end{array}$ \\
\hline & & $\begin{array}{l}\text { This method detects current } \\
\text { infections of disease, can } \\
\text { determine who is currently infected } \\
\text { and who is not in population }\end{array}$ & $\begin{array}{l}\text { Sometime false positive results may } \\
\text { occur due to non-specific } \\
\text { amplifications, so need highly skilled } \\
\text { expertise in designing the kit } \\
\text { components and detection }\end{array}$ \\
\hline 2 & Serological method & $\begin{array}{l}\text { Lateral flow immunoassays are } \\
\text { simple devices and easy to read } \\
\text { that can detect antibodies (lgM/lgG) } \\
\text { in the blood for both current and } \\
\text { past infection of COVID-19 }\end{array}$ & $\begin{array}{l}\text { Unlike RT-PCR and ELISA, Lateral flow } \\
\text { tests are time consuming and more } \\
\text { expensive for large number of samples. } \\
\text { As this technology is new, its reliability } \\
\text { is still under evaluation }\end{array}$ \\
\hline
\end{tabular}
long-term track of antibody response, antibody abundance and its diversity

It is economical in terms of time (15 min to $2 \mathrm{~h}$ ) and cost than RT-PCR, and techniques like ELISA is well established within science and medicine

ELISA can be used as rapid testing for multiple samples at once, so can be scaled up for large number of testing

It is a cheap, quick and non-invasive virus detection method that relies on unique spectral signature of nanostructure of SARS-CoV-2

This method can be used for an in vivo point-of-care detection tool
The technique is quick, sensitive and reliable with higher accuracy and precision rate, low sample requirement, simple procedure The nanoparticles can be amalgamated to any of the classical technique for improvement of their detection efficacy

The nano-based techniques can be customized based on luminosity, chromogenic effect, acoustic effect, photothermal effect
Cai X.-F. et al., 2020; Green et al., 2020; Udugama et al., 2020; Xiang et al., 2020

\section{References}

Lauri and Mariani, 2009; Green et al., 2020; Udugama et al., 2020

Despite of hard work of several companies, ELISA tests are at preliminary stage for SARS-CoV-2 COVID 19 testing

Unknown

This method faces the challenge of fluorescence, background signals and laser intensity below ANSI limit

Desai et al., 2020; Jacobi et al., 2020; Khan and Rehman, 2020

This method cannot be used for vaccine development, and failed to track the antibody response and its abundance \& diversity

Cost-deficit and limited clinical experimentation
Baptista, 2014;

Urio et al., 2015; Campos et al., 2020; Weiss et al., 2020 
TABLE 2 | List of different possible antiviral drugs available for SARS-CoV-2.

\begin{tabular}{lll}
\hline Generic name & $\begin{array}{l}\text { Conventional } \\
\text { application }\end{array}$ & Mechanism of action (broad sense) \\
\hline Baricitinib (MW: & $\begin{array}{l}\text { Applied against } \\
\text { rheumatoid } \\
\text { arthritis }\end{array}$ & $\begin{array}{l}\text { JAK inhibitor: Baricitinib reversibly } \\
\text { inhibits Janus kinase 1, Janus kinase 2, } \\
\text { Janus kinase } 3 \text { and Tyrosine kinase 2 } \\
\text { (which belongs to the same enzyme } \\
\end{array}$ \\
& $\begin{array}{l}\text { family) via a signal transduction } \\
\text { pathway involving STAT proteins which } \\
\text { ultimately modulates gene expression in } \\
\end{array}$ & immunological cells
\end{tabular}

Lopinavir (MW: $\quad$ Applied with a $628.8 \mathrm{~g} / \mathrm{mol})$

Ritonavir (MW: $720.9 \mathrm{~g} / \mathrm{mol})$ combination of ritonavir to treat and prevent HIV/AIDS

Applied to treat HIV infection
Protease Inhibitor: Lopinavir used as an antiretroviral protease inhibitor which applied with combination of other antiretrovirals. It is a peptidomimetic molecule and contains a hydroxyethylene scaffold which imitates the linkage of peptides of protease enzymes that targeted by the HIV-1 protease, thus preventing the activity of the HIV-1 protease.

Protease Inhibitor: Ritonavir considered as a HIV protease inhibitor which interact with cytochrome P450-3A4 (CYP3A4) that abundantly found in intestines and liver
Darunavir (MW: Applied to treat $547.7 \mathrm{~g} / \mathrm{mol}$ ) and prevent HIV/AIDS

Favipiravir (MW: $157.1 \mathrm{~g} / \mathrm{mol}$ )
Applied to fight against Influenza virus
Protease inhibitor: Darunavir is a non-peptidic inhibitor of protease that lodges itself in the active site of protease through a number of hydrogen bonds. As a result, it is developing to increase interactions with HIV-1 protease

RNA polymerase inhibitor: Favipiravir is a pyrazinecarboxamide derivative which helps to convert the ribofuranosyltriphosphate derivative by host enzymes and selectively inhibits the influenza viral RNA-dependent RNA polymerase

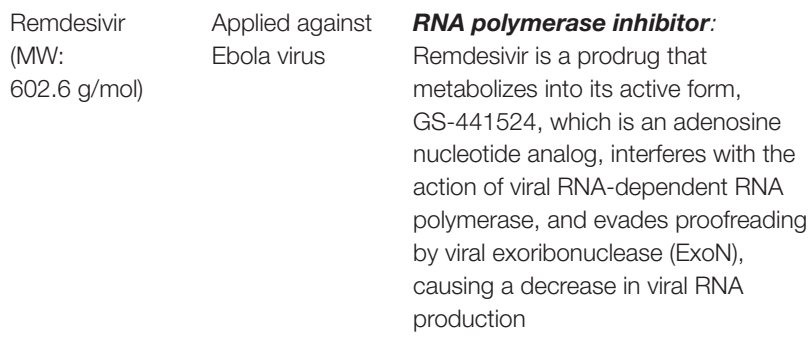

Remdesivir

(MW:

$602.6 \mathrm{~g} / \mathrm{mol}$ )

Applied against Ebola virus

RNA polymerase inhibitor:

Remdesivir is a prodrug that metabolizes into its active form, GS-441524, which is an adenosine nucleotide analog, interferes with the action of viral RNA-dependent RNA polymerase, and evades proofreading by viral exoribonuclease (ExoN), causing a decrease in viral RNA production

Chu et al. (2004) reported lopinavir and ribavirin at the concentrations of $4 \mu \mathrm{g} / \mathrm{ml}$ and $50 \mu \mathrm{g} / \mathrm{ml}$, respectively, is effective against in vitro antiviral activity against SARS associated coronavirus

Dong et al. (2020) found positive results when combined administrated with lopinavir at a ratio of 200: 500 mg/capsule (lopinavir: ritonavir, respectively)

Harrison (2020) has proven the antiviral activity against COVID-19

Cai Q. et al. (2020) reported the effectiveness of favipiravir in 35 patients (out of 80) demonstrated significantly shorter viral clearance time, however, the exact mechanism is unknown. A regiment of 3200 mg (1600 mg twice daily) loading dose on day-1 followed by 1200 mg maintenance dose $(600 \mathrm{mg}$ twice daily) on day-2 to day-14

Wang M. et al. (2020) experimented on COVID 19 patients and found the EC90 value of remdesivir in Vero E6 cells was $1.76 \mu \mathrm{M}$, suggesting its effectiveness
Side effects

- Promotes upper respiratory tract infections and cholesterol levels in blood

- Develops herpes zoster, herpes simplex, urinary tract infections, and gastroenteritis

- Causes diarrhea, headache, nausea, vomiting, stomach upset, drowsiness, dizziness, taste abnormality and trouble in sleeping

- Helps to develop asthenia, malaise diarrhea, nausea, vomiting, abdominal pain, dizziness, insomnia, sweating, taste abnormality, abnormality in metabolic activities

- Induces diarrhea, nausea, abdominal pain, headache and body rash

- Causes mild to moderate diarrhea, asymptomatic increase of blood uric acid and transaminases

- Decreases the number of neutrophils

- Increases enzyme levels in liver

- Causes nausea and vomiting
References

Winthrop, 2017;

Richardson et al., 2020

Chu et al., 2004;

Lemmer and

Liebenberg, 2013

Zeldin and Petruschke, 2004; Dong et al., 2020

Harrison, 2020

Cai Q. et al., 2020; Du and Chen, 2020; Shiraki and Daikoku, 2020

Agostini et al., 2018; Boettler et al., 2020; Wang M. et al., 2020 
TABLE 2 | Continued

\begin{tabular}{|c|c|c|c|c|c|}
\hline Generic name & $\begin{array}{l}\text { Conventional } \\
\text { application }\end{array}$ & $\begin{array}{l}\text { Mechanism of action (broad } \\
\text { sense) }\end{array}$ & $\begin{array}{l}\text { Effective evidences against } \\
\text { Coronavirus }\end{array}$ & Side effects & References \\
\hline $\begin{array}{l}\text { Ribavirin (MW: } \\
244.2 \mathrm{~g} / \mathrm{mol})\end{array}$ & $\begin{array}{l}\text { Applied to treat } \\
\text { RSV infection, } \\
\text { hepatitis C and } \\
\text { some viral } \\
\text { hemorrhagic fevers }\end{array}$ & $\begin{array}{l}\text { Nucleoside inhibitor: } \\
\text { Ribavirin is a guanosine analog } \\
\text { which stops viral RNA synthesis } \\
\text { and viral mRNA capping. In this } \\
\text { way, it interferes with the RNA } \\
\text { metabolism required for viral } \\
\text { replication }\end{array}$ & $\begin{array}{l}\text { Khalili et al. (2020) predicted } \\
\text { the effectiveness of ribavirin } \\
\text { individually or with the } \\
\text { combination of either } \\
\text { IFN- } \alpha / \text { /opinavir/ritonavir. They } \\
\text { had also stated the use of this } \\
\text { drug during SARS and MERS } \\
\text { outbreak }\end{array}$ & $\begin{array}{l}\text { - Causes nausea, } \\
\text { tiredness, chills or } \\
\text { shaking, headache, } \\
\text { mood changes, feeling } \\
\text { irritable, muscle and } \\
\text { stomach pain, vomiting } \\
\text { and loss of appetite }\end{array}$ & $\begin{array}{l}\text { Loustaud-Ratti et al., } \\
2016 \text {; Khalili et al., } \\
2020\end{array}$ \\
\hline $\begin{array}{l}\text { Galidesivir } \\
\text { (MW: } \\
265.27 \mathrm{~g} / \mathrm{mol} \text { ) }\end{array}$ & $\begin{array}{l}\text { Applied against } \\
\text { RNA viruses like } \\
\text { Flaviviruses, } \\
\text { Togaviruses, } \\
\text { Bunyaviruses, } \\
\text { Arenaviruses, } \\
\text { Paramyxoviruses, } \\
\text { Coronaviruses, } \\
\text { Filoviruses, } \\
\text { Orthomyxoviruses } \\
\text { and Picornaviruses }\end{array}$ & $\begin{array}{l}\text { Nucleoside RNA polymerase } \\
\text { inhibitor: Galidesivir works by } \\
\text { binding to viral RNA } \\
\text { polymerase where the natural } \\
\text { nucleotide would bind, leading } \\
\text { to a structural change in the } \\
\text { viral enzyme due to altered } \\
\text { electrostatic interactions }\end{array}$ & $\begin{array}{l}\text { Elfiky (2020) predicted about } \\
\text { galidesivir through molecular } \\
\text { docking and postulated that it } \\
\text { may tightly bind to the RdRp of } \\
\text { the SARS-CoV-2 strain. The } \\
\text { drug is currently in advanced } \\
\text { development stage under } \\
\text { animal trial to combat multiple } \\
\text { potential viral threats including } \\
\text { coronaviruses }\end{array}$ & $\begin{array}{l}\text { - No notable adverse } \\
\text { effects }\end{array}$ & $\begin{array}{l}\text { Vickers, 2017; } \\
\text { Westover et al., 2018; } \\
\text { Eyer et al., 2019; Elfiky, } \\
2020\end{array}$ \\
\hline $\begin{array}{l}\text { Arbidol (MW: } \\
477.4 \mathrm{~g} / \mathrm{mol})\end{array}$ & $\begin{array}{l}\text { Applied against a } \\
\text { number of } \\
\text { enveloped and } \\
\text { non-enveloped } \\
\text { viruses }\end{array}$ & $\begin{array}{l}\text { Cell membrane endocytosis } \\
\text { inhibitor: Arbidol helps to } \\
\text { inhibit the entry of cell by } \\
\text { blocking/fusing with host cell } \\
\text { membrane }\end{array}$ & $\begin{array}{l}\text { Dong et al. (2020) reported } \\
\text { about the clinical trial of this } \\
\text { drug with } 200 \mathrm{mg}, 3 \text { times/day } \\
\text { may help to reduce the } \\
\text { infection, but exact interaction } \\
\text { is unknown. }\end{array}$ & $\begin{array}{l}\text { Develops nausea, } \\
\text { diarrhea, dizziness and } \\
\text { elevated serum } \\
\text { transaminase }\end{array}$ & $\begin{array}{l}\text { Boriskin et al., 2008; } \\
\text { Huang et al., 2017; } \\
\text { Dong et al., } 2020\end{array}$ \\
\hline $\begin{array}{l}\text { Chloroquine } \\
\text { (MW: } \\
319.9 \mathrm{~g} / \mathrm{mol} \text { ) }\end{array}$ & $\begin{array}{l}\text { Applied to prevent } \\
\text { or treat the malaria }\end{array}$ & $\begin{array}{l}\text { Inhibition of } \\
\text { MATE1-mediated metformin } \\
\text { transport by chloroquine: } \\
\text { Chloroquine inhibiting the } \\
\text { formation of hemozoin from the } \\
\text { heme that are released by the } \\
\text { digestion of hemoglobin. The } \\
\text { free heme then lyses } \\
\text { membranes and leads to arrest } \\
\text { the parasite. It also directly } \\
\text { involved various molecular } \\
\text { pathways in lysosomal activity, } \\
\text { autophagy and signal } \\
\text { transduction }\end{array}$ & $\begin{array}{l}\text { Wong et al. (2020) discussed } \\
\text { the advice given by the National } \\
\text { Health Commission of the } \\
\text { People's Republic of China } \\
\text { mentioning a dose of } 500 \mathrm{mg} \\
\text { twice per day for no more than } \\
10 \text { days best suitable for adults. } \\
\text { Vincent et al. (2005) } \\
\text { experimented with the } \\
\text { effectiveness of chloroquine by } \\
\text { observing the nature of Vero E6 } \\
\text { cells with respect to SARS-CoV } \\
\text { infection }\end{array}$ & $\begin{array}{l}\text { Results loss of appetite, } \\
\text { mild dizziness. mild } \\
\text { diarrhea, clumsiness, } \\
\text { mild headache, nausea } \\
\text { and stomach cramps }\end{array}$ & $\begin{array}{l}\text { Vincent et al., 2005; } \\
\text { Wong et al., } 2020\end{array}$ \\
\hline $\begin{array}{l}\text { Nitazoxanide } \\
\text { (MW: } \\
307.28 \mathrm{~g} / \mathrm{mol})\end{array}$ & $\begin{array}{l}\text { Applied to treat } \\
\text { various helminthic } \\
\text { as well as protozoal } \\
\text { parasites and viral } \\
\text { infections }\end{array}$ & $\begin{array}{l}\text { Interference with } \\
\text { host-regulated pathways: } \\
\text { Nitazoxanide inhibits the } \\
\text { replication of a broad range of } \\
\text { other RNA and DNA viruses } \\
\text { including respiratory syncytial } \\
\text { virus }\end{array}$ & $\begin{array}{l}\text { McCreary and Pogue. (2020) } \\
\text { reviewed the application of } \\
\text { nitazoxanide which supports a } \\
\text { potent in vitro activity against } \\
\text { SARS CoV-2, by observing } \\
\text { certain characteristics of Vero } \\
\text { E6 and LLC-MK2 cells. } \\
\text { Rossignol (2016) concluded } \\
\text { that this might be due to } \\
\text { interference with host-regulated } \\
\text { pathways which are involved in } \\
\text { viral replication rather than } \\
\text { virus-specific pathways }\end{array}$ & $\begin{array}{l}\text { Develops nausea, } \\
\text { stomach pain, } \\
\text { headache, discolored } \\
\text { urine }\end{array}$ & $\begin{array}{l}\text { Rossignol, 2014, 2016; } \\
\text { McCreary and Pogue, } \\
2020\end{array}$ \\
\hline $\begin{array}{l}\text { IFN- } \alpha \text { (MW: } \\
19.5 \mathrm{kDa})\end{array}$ & $\begin{array}{l}\text { Applied against } \\
\text { chronic hepatitis B } \\
\text { (HBV) and hepatitis } \\
\text { C virus (HCV) } \\
\text { infections }\end{array}$ & $\begin{array}{l}\text { DNA synthesis inhibitor: } \\
\text { IFN- } \alpha \text { may inhibit the DNA } \\
\text { synthesis in meningioma cells } \\
\text { induced by platelet-derived } \\
\text { growth factor and epidermal } \\
\text { growth factor }\end{array}$ & $\begin{array}{l}\text { Sallard et al. (2020) discussed } \\
\text { the broad antiviral applications } \\
\text { of IFN- } \alpha \text { under in vitro and } \\
\text { clinical trials' data says it is } \\
\text { more effective in the early } \\
\text { stages of infection. It interferes } \\
\text { with the replication machinery }\end{array}$ & $\begin{array}{l}\text { - Swells or other reactions } \\
\text { may persist at the } \\
\text { injection site } \\
\text { - Causes headache, } \\
\text { tiredness, nausea, } \\
\text { vomiting, diarrhea, } \\
\text { trouble in sleeping }\end{array}$ & $\begin{array}{l}\text { Ragel and Jensen, } \\
\text { 2003; Dong et al., } \\
\text { 2020; Sallard et al., } \\
2020\end{array}$ \\
\hline
\end{tabular}

of viruses and slows down the metabolic processes 
reaction. Then, the transducer converts changes to a signal quantified by the detector (Verma and Bhardwaj, 2015). These can be categorized into five classes, that include electrochemical (Eissa et al., 2015), optic (Saylan et al., 2017), piezoelectric (Battal et al., 2018), thermal (Yang et al., 2016), and magnetic-based nanosensors (Wang et al., 2016). These sensors have been widely investigated to meet the requirements for clinical diagnostics, consisting of high sensitivity and early detection of several diseases (Baptista, 2014). Viral infections, like HIV, are mostly diagnosed via enzyme-linked immunosorbent assay (ELISA), that detects if HIV antibodies such as IgM/IgG are present or not (Urio et al., 2015).

There are different types of nanoparticulated systems (inorganic, organic, and hybrid NPs/nanosystems) which are classified based on their composition and can be exploited to develop an advanced and versatile detection system. For example, Lee et al. (2013) reported an electrochemical method for detecting the direct electron transfer signal from the HIV-1 virus through exploiting nanotechnology. In this method, AuNPs were electrodeposited onto the indium tin oxide coated glass (ITO) electrode to provide a higher background charging current and good electron transfer kinetics. AuNPs-antibody fragments were immobilized and modified with the ITO electrode using the self-assembly method through gold-thiol interactions. The technique was successful in detecting virus like particles from 600 to $375 \mathrm{pg} / \mathrm{ml}$. Inan et al. (2017) developed a microfluidic nanosensor for the detection of human papillomavirus (HPV)$16 \mathrm{E} 7$ antibodies and observed identification down to $2.87 \mathrm{ng} / \mathrm{ml}$. The nanosensor was validated in serum samples and it was shown that the nanosensor could be engaged as a pretesting tool for the diagnostics of broad-spectrum monitoring of HPVassociated cancer. A digital nanosensor to detect the Ebola virus was developed by Natesan et al. (2019). This nanosensor had a flow cell assay that caught specific antibodies with microarrayed recombinant antigens and a smartphone fluorescent reader for high-performance elucidation of results. They showed that the smartphone reader had a hardware which connected to the back of a smartphone and provided the user with an interface to handle the operation, communicate with cloud services and acquire test results, and also developed a safe cloud service for the tele-monitoring of results (Natesan et al., 2019). Carbon-NPs-modified screen-printed carbon electrode (SPCE)-based electrochemical biosensor strip for rapid and sensitive detection of the Japanese Encephalitis Virus (JEV) was developed by Lai et al. (2017). Hamdy et al. (2018) developed an ultrasensitive AuNPs biosensor functionalized with thiol-linked oligonucleotides, which could recognize conserved RNA standards of foot and mouth disease virus (FMDV). Recently, Chowdhury et al. (2019) also developed a pulsetriggered ultrasensitive electrochemical sensor for the detection of Hepatitis E virus (HEV). Here, the group engineered a specific anti-HEV antibody-conjugated to nitrogen- and sulfurco-doped graphene quantum dots (Ab-N and S-GQDs) and AuNPs-embedded polyaniline nanowires as the electrode matrix of the sensor. A colorimetric assay that detects HIV infection based on gold nanoparticles along with functional split aptamers has been developed for the detection of HIV-1 Tat protein, which is a transactivator of HIV gene expression (Fatin et al., 2019). Currently, a selective 'naked-eye' colorimetric assay based on AuNPs for the detection of SARS-CoV-2 has been developed by Moitra et al. (2020). Here, AuNPs capped with antisense oligonucleotides (ASO) specific for the N-gene (nucleocapsid phosphoprotein) of SARS-CoV-2 were developed that agglomerated selectively in the presence of its target RNA sequence and demonstrated a change in its surface plasmon resonance (SPR). These investigations are practical examples that suggest the applicability of nanotechnology in the detection of SARS-CoV-2 in future research.

\section{NANOTECHNOLOGICAL ADVANCEMENT IN INHIBITION OF VIRAL INFECTION}

With an aim of constructing a next generation nano-delivery system, researchers have shifted their curiosity to organic nanomaterials from inorganic NPs. With an effort to comprehend the intricacy of the body and to elude multiple veneers of defense of the host, it is necessary to depend on the capacity of certain materials to interact with specific components, without altering the host's homeostasis (Weiss et al., 2020). Though organic nanomaterials are preferred over inorganic NPs, their efficacy and applicability in research involving viral inhibition are scanty. In the last two decades, inorganic NPs have been widely investigated for viral inhibition. Some of these include the use of graphene oxide (GO), which can effectively inactivate pathogenic agents of avian influenza A virus $\mathrm{H} 9 \mathrm{~N} 2$ and hand-foot-and-mouth disease EV7I, at $56^{\circ} \mathrm{C}$ (Song et al., 2015). GO composites functionalized with cyclodextrin and loaded with a high amount of curcumin could significantly inhibit infection of respiratory syncytial virus (Yang et al., 2017). Further, Lee et al. (2016) observed that solid and mesoporous silicon NPs functionalized with mimetic glycosaminoglycan could inhibit the entry of herpes simplex virus type 1 and type 2 into host cells. Mesoporous silicon NPs modified with different surface groups could effectively bind with the viruses through hydrophobic interactions and reduced the ability of the virus to infect host cells (de Souza et al., 2016).

Presently, numerous investigations exploiting organic nanomaterials for engineering nano-based viral inhibiting agents are being carried out. Kondel et al. (2019) have shown the control-release of acyclovir encapsulated in solid lipid nanoparticles (SLN) in a BALB/c mice model infected with herpes simplex virus (HSV)-1. Lauster et al. (2020) engineered phage capsid NPs functionalized with a sialic acid ligand to match the binding sites of the homotrimeric hemagglutinin to block influenza A virus entry in BALB/c mice. Their research demonstrated that the phage capsid NPs were effective against the virus and had no immunogenic impact on the host. Moreover, Wang W. et al. (2020) recently developed a dual-targeting ferritin NPs vaccine that could elicit an immunological response against chronic HBV in C57BL/6 mice. Here, the ferritin NP vaccine was synthesized by conjugating purified SpyCatcher-preS1 (SC-preS1) fused to SpyTag-ferritin NP. The preS1 conjugated with ferritin NP vaccine could simultaneously bind and induce 

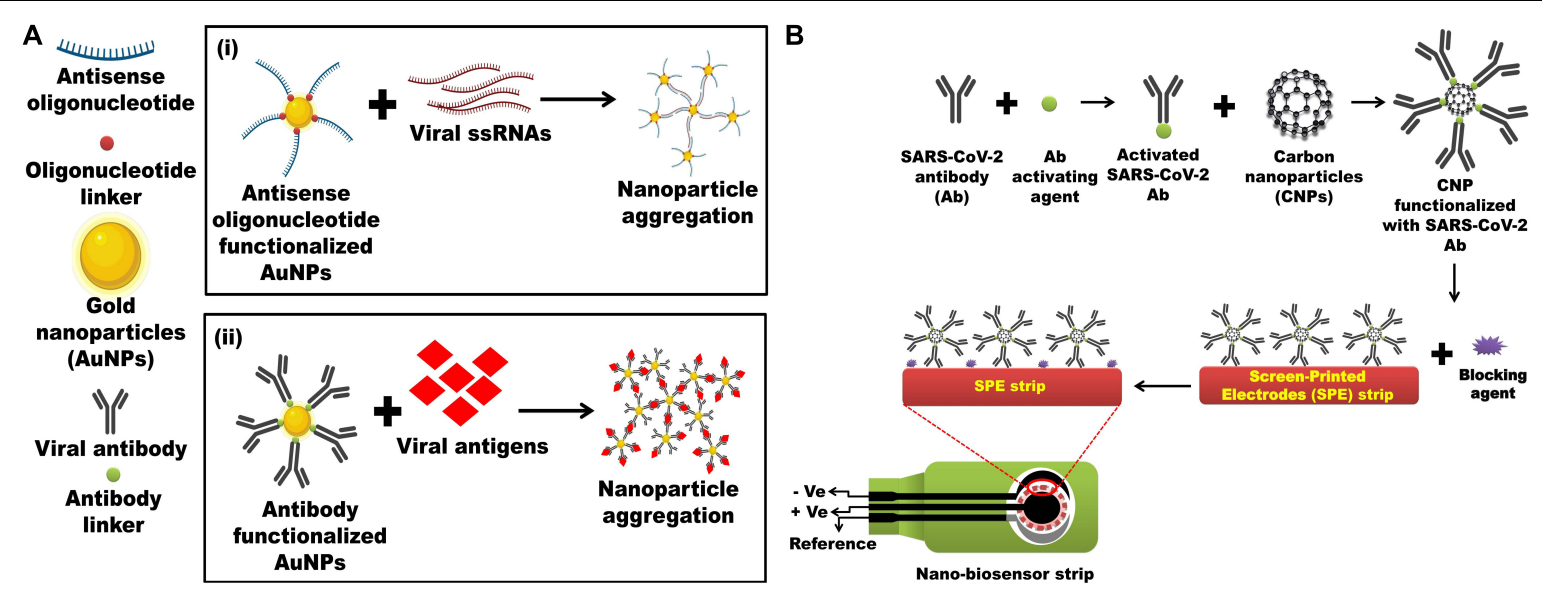

FIGURE 2 | Nanotechnology-based detections of SARC-CoV-2 antigen or the whole virus. (A) (i) Multiple fragments of antisense-oligonucleotides against ORF1a/ORF1b/nsp3/nsp4/nsp5 functionalized on the surface of AuNPs. Antisense-oligonucleotides linked AuNPs binds with digested viral sample containing ORF1a/ORF1b/nsp3/nsp4/nsp5 genomic ssRNA, resulting in AuNPs aggregation which can be visualized spectrophotometrically as the color of solution changes from red to blue/purple. Inspired from Jacobi et al. (2020). (ii) Antibody against SARS-CoV-2 proteins such as S, E, and N protein and main proteinase (Mpro also called 3CLpro) functionalized on the surface of AuNPs will also aggregate after incubating digested viral sample containing SARS-CoV-2 proteins which can be visualized spectrophotometrically as the color of solution changes from red to blue/purple. Inspired from Jazayeri et al. (2018). (B) Screen-printed carbon electrode (SPCE) electrochemical biosensor strip can be designed against 2019-nCoV by exploiting the SARS-CoV-2 antibody immobilized onto the surfaces of carbon NPs (CNPS) through amide bonds formed between amino groups of CNPs and carboxylic groups of SARS-CoV-2 antibody. Inspired from Chowdhury et al., 2019.

SIGNR1 + dendritic cells (which activate T follicular helper cells) and lymphatic sinus-associated SIGNR1 + macrophages (which can activate B cells). Recently, $\mathrm{Hu}$ et al. (2020) commented on the therapeutic prospective of nanomedicine and chloroquine against COVID-19.

\section{FUTURE PROSPECTS OF SARS-CoV-2 DETECTION THROUGH NANOTECHNOLOGY-BASED APPROACHES}

Keeping these NPs-based biosensors as a reference, it is possible to develop nanobiosensors for the rapid and ultrasensitive detection of SARS-CoV-2. Hypothetically, an Au-NPs biosensor functionalized with thiol-linked oligonucleotides against ORF1a/ORF1b/nsp3 (viral protease) can be developed for the diagnosis of SARS-CoV-2 (Figure 2A). Optical properties of AuNPs are hugely considered and have the possibility for use in the recognition of chemical and biological materials (Jazayeri et al., 2018). A unique property of non-aggregate and aggregate modes of AuNPs is their ability to change color, which can be easily discriminated by UV spectrophotometer and can be effectively exploited for SARS-CoV-2 detection. Thus, in the current hypothesis, multiple fragments of antisense oligonucleotides against ORF1a/ORF1b/nsp3 can be functionalized on the surface of AuNPs. Then, these antisense oligonucleotides linked to AuNPs when added to a digested viral sample containing ORF1a/ORF1b/nsp3 genomic ssRNA, which will result in AuNPs aggregation. This can be qualitatively analyzed via spectroscopic methods as the color of solution changes from red to blue/purple (Figure 2A). Additionally, a carbon NPs electrochemical biosensor strip or a screen-printed carbon electrode (SPCE) electrochemical biosensor strip can be designed against 2019-nCoV by exploiting the SARS-CoV-2 antibody immobilized onto the surfaces of carbon NPs through amide bonds formed between amino groups of carbon NPs and carboxylic groups of SARS-CoV-2 antibodies. Similarly, for increasing the efficacy of the strip antibody against any of these viral proteins, like $\mathrm{S}, \mathrm{E}$, and $\mathrm{N}$ protein and main proteinase (Mpro also called 3CLpro), they can also be incorporated for the detection of the viral infection (Figure 2B). Again, surface proteins of SARS-CoV-2 could provide a unique spectral signature under low-frequency Raman spectroscopy, which will not be decayed by laser excitation. Therefore, a unique lowfrequency Raman spectral signature of the whole virus or specific viral proteins can be generated and exploited as a novel identifier of the virus and viral protein components (Jacobi et al., 2020).

\section{FUTURE PROSPECTS OF SARS-CoV-2 INHIBITION THROUGH NANOTECHNOLOGY-BASED APPROACHES}

In addition to eliminating and/or neutralizing the adverse impacts of the antiviral drugs, it is complementary to devise a strategy for provoking or modulating the host cell intracellular cascades, like autophagy, inflammasome, apoptosis, and epigenetics, to act against the viral infection. The adverse impacts of these antiviral drugs are mostly due to their unambiguous target of action on both infected and uninfected cells, that occur at multiple locations of the host (Mohammadi Pour et al., 2019; Mishra et al., 2020). Nanotechnology-based advancements 

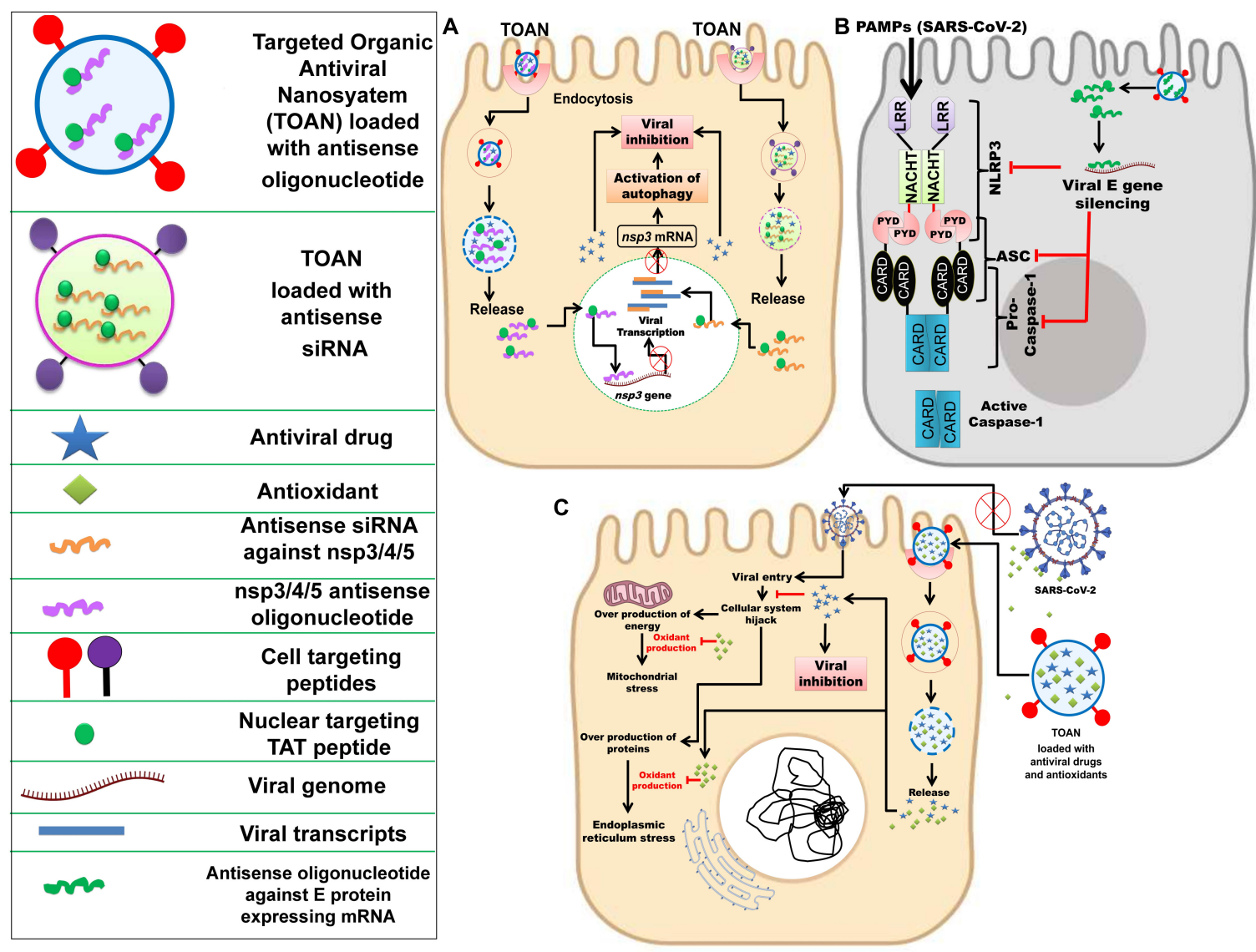

FIGURE 3 | Nanotechnology-based inhibition mechanisms of SARC-CoV-2. (A) Delivery of nuclear targeting TAT peptide tagged antisense siRNA against nsp3/4/5 or TAT peptide tagged nsp3/4/5 antisense oligonucleotide along with an antiviral drug through targeted organic antiviral nanosystem (TOAN) to SARS-CoV-2 infected goblet cell, resulting in activation of autophagy and viral inhibition. Inspired from Pan et al. (2012); Chen et al. (2018), Panigrahi et al. (2018), and Pala et al. (2019). (B) Delivery of antisense oligonucleotide against SARS-CoV-2 E gene through TOAN to SARS-CoV-2 infected goblet cell, resulting in viral E gene and arrest of NLRP3. Inspired from Nieto-Torres et al. (2015); Siu et al. (2019), and Conti et al. (2020). (C) Delivery of antioxidants (flavonoids) and antiviral drugs through TOAN to SARS-CoV-2 infected goblet cell, resulting viral entry inhibition and destruction with complimentary antioxidant effect to neutralize mitochondrial and endoplasmic reticulum stress. Outside the infected cell, antioxidant compounds could effectively bind viral S protein and prevent its entry into the cell. Inspired from Galluzzi et al. (2017); El-Hamid et al. (2018), and Jena et al. (2020).

that have been made to combat these limitations are reviewed comprehensively by Kerry et al. (2019).

Taking into consideration these above-mentioned technological advancements made over the past decade, a nano-based antiviral drug and vaccine against SARS-CoV-2 can be proposed. To eliminate the adverse impact of antiviral drugs in COVID-19 patients, target-specific delivery of the antiviral drugs to goblet and ciliated cells are the basis, as these cells are the primary target of SARS-CoV-2 (Lukassen et al., 2020). Organic (polymeric/peptide) NPs encapsulating antiviral drugs can be functionalized with a goblet cell targeting agent, i.e., CSKSSDYQC peptide (Chen et al., 2018) and an antibody against dopamine-receptor type-5 (DR-5) [largely expressed in ciliated cells] for target-specific delivery of antiviral drugs (Pala et al., 2019). The efficiency of the hypothesized Targeted Organic Antiviral Nanosystem (TOAN) could be further enhanced by conjugating it with appropriate intracellular cascades (autophagy, inflammasome, and apoptosis) modulating agents.

To effectively inhibit SARS-CoV-2, it is essential to identify the targeting intracellular viral components within the host, like various non-structural genes nsp3, nsp4, and nsp5. The nsp5 encodes 3CLpro which cleaves the replicase polyprotein pplab at the C-terminus at 11 sites, releasing nsp4-nsp16 that are essential in the viral life-cycle. The monomer of 3Clpro contains three domains and its active site that possesses a catalytic dyad of Cys145 and His 41 is located in between domain I and II (Wu C. et al., 2020). The chymotrypsin like protease plays an important role in processing pplab and viral replication (Mahdian et al., 2020; ul Qamar et al., 2020). As mentioned earlier, the nsp3encoded PLpro enzyme cleaves the pplab at three distinct sites. In the case of coronavirus infection, it inhibits autophagosome to fuse with the lysosome and blocks the host's immune response, promoting cytokine expression (Chen et al., 2014; Yin, 2020). 
For instance, in SARS-CoV-2-infected cells, activation of autophagy and viral inactivation can be simultaneously achieved by loading the TOAN with nuclear targeting TAT peptide tagged nsp3 antisense oligonucleotides/antisense siRNA (Pan et al., 2012; Panigrahi et al., 2018) (Figure 3A).

Further, the inhibition of the E protein may cause inactivation of inflammasomes as per Fung et al. (2020). But inflammasome initiation is mediated due to secretion of various inflammatory cytokines. However, the higher expression of cytokines can be reduced by inhibition of PLpro and this may subsequently inhibit inflammasome activation and blocking of the host's innate immune response. Therefore, targeting PLpro along with 3CLpro could be a better therapeutic strategy. Siu et al. (2019) and Conti et al. (2020) highlighted the activation of NLPR3 inflammasome and secretion of IL- $1 \beta$ in SARS-CoV-infected cells, and previously Nieto-Torres et al. (2015) explained the virulent role of $\mathrm{E}$ protein toward the activation of NLRP3 inflammasome. Thus, to prevent NLRP3 inflammasome in the infected host cell, the TOAN can be conjugated with antisense oligonucleotides against SARS-CoV-2 E gene (Figure 3B).

The nsp4 is responsible for the formation of double membrane vesicle (DMV) and, likewise, other non-structural proteins are associated with several vital functions involved in virus maturation (Yin, 2020). Despite significant homology to SARSCoV 3CLpro, the 3CLpro of SARS-CoV-2 is a conserved sequence due to some key differences in its substrate binding site. As 3CLpro is accountable for the processing of vital nonstructural proteins (nsp4-nsp16), the conserved structure or its active site may serve as a target for antiviral therapies. Moreover, targeting 3CLpro may also prevent DMV formation due to the inactivation of nsp4 that may further inhibit ER stress because DMV is originated from ER of the host. Further, it is clear from previous studies that ER stress is one of the most well-regarded outputs of viral infection within the host cell. It is also understood that ER stress can have several deleterious effects on the maintenance of intracellular homeostasis, thereby compromising a cell's ability to sustain and proliferate despite the infection, as well as perform its other regulatory functions as a part of a larger tissue system. Therefore, the exogenous reliving of intracellular ER stress by the utilization of natural antioxidants (flavonoids and terpenoids) would be complimentary with targeting nsp4 gene. Recently, computational studies have confirmed the ability of natural antioxidant flavonoids, like curcumin and catechin, to be proficient in binding and blocking the SARS-CoV-2 S protein (Galluzzi et al., 2017; El-Hamid et al., 2018; Jena et al., 2020). Hence, synthesizing TOAN in conjunction with these antioxidant

\section{REFERENCES}

Adhikari, S. P., Meng, S., Wu, Y.-J., Mao, Y.-P., Ye, R.-X., Wang, Q.-Z., et al. (2020). Epidemiology, causes, clinical manifestation and diagnosis, prevention and control of coronavirus disease (COVID-19) during the early outbreak period: a scoping review. Infect. Dis. Poverty 9:29. doi: 10.1186/s40249-020-00646-x

Agostini, M. L., Andres, E. L., Sims, A. C., Graham, R. L., Sheahan, T. P., Lu, X., et al. (2018). Coronavirus susceptibility to the antiviral remdesivir (GS-5734) is mediated by the viral polymerase and the proofreading exoribonuclease. $m B i o$ 9:e00221-18 doi: $10.1128 / \mathrm{mBio} .00221-18$ flavonoids would be effective against SARS-CoV-2 (Figure 3C). A nano-based vaccine can also be designed against SARS-CoV2 by exploiting the $S$ protein, a conserved immunogenic epitope (Ou et al., 2020; Wang W. et al., 2020).

\section{CONCLUSION}

The sudden emergence of SARS-CoV-2, along with its highly contagious nature, has affected countries and rattled societies throughout the globe. Researchers across the world have made advancements in characterization and are presently in search of effective detection and inhibition tactics. Therefore, this paper summarizes the available scientific knowledge of SARSCoV-2's structure and pathogenesis to better understand the virus. The paper also highlights the impaired and incomplete autophagy process induced by viral nsp3-encoded protease, enhanced ER stress, and apoptosis promoted through the generation of viral double-membrane vesicles, as well as posttranslational modifications of viral proteins. Further, the viral immunological response, envelope protein-mediated activation of NLRP3 inflammasome, and the genetic and epigenetic changes of host cells are also described. As a future prospective, the review has outlined two feasible colorimetric detection strategies that exploit AuNPs and nanosensors based on CNPs for the detection of SARS-CoV-2. Lastly, considering the requirement of an effective viral elimination method, three nano-based strategies have also been illustrated by using versatile organic nanodelivery system which need further investigation. Thus, the review provides a platform for present investigators to develop a competent method for SARS-CoV-2 detection and inhibition.

\section{AUTHOR CONTRIBUTIONS}

SP, RK, and SK wrote the initial draft. JR was credited for the first comprehensive edit, which was then reviewed and edited by GM and BP. All the authors read and approved the final manuscript.

\section{ACKNOWLEDGMENTS}

The authors are grateful to the authorities of their respective universities for providing the platform for this review and Prof. Niranjan Behera, Dean, School of Biological Sciences, AIPH University for reviewing the manuscript. 
disease from Saudi Arabia: a descriptive study. Lancet Infect. Dis. 13, 752-761. doi: 10.1016/S1473-3099(13)70204-4

Astuti, I., and Ysrafil (2020). Severe acute respiratory syndrome coronavirus 2 (SARS-CoV-2): an overview of viral structure and host response. Diabetes Metab. Syndr. 14, 407-412. doi: 10.1016/j.dsx.2020.04.020

Baptista, P. V. (2014). Nanodiagnostics: leaving the research lab to enter the clinics? Diagnosis 1, 305-309. doi: 10.1515/dx-2014-0055

Battal, D., Akgönüllü, S., Yalcin, M. S., Yavuz, H., and Denizli, A. (2018). Molecularly imprinted polymer based quartz crystal microbalance sensor system for sensitive and label-free detection of synthetic cannabinoids in urine. Biosens. Bioelectron. 111, 10-17. doi: 10.1016/j.bios.2018.03.055

Bello-Perez, M., Sola, I., Novoa, B., Klionsky, D. J., and Falco, A. (2020). Canonical and noncanonical autophagy as potential targets for COVID-19. Cells 9:E1619. doi: $10.3390 /$ cells 9071619

BGI (2020a). BGI Responds to Novel Coronavirus with Real-Time Detection Kits, Deploys Emergency Team to Wuhan. Available online at: https: //www.bgi.com/global/company/news/bgi-responds-to-novel-coronaviruswith-real-time-detection-kits-deploys-emergency-team-to-wuhan/ (accessed July 30, 2020).

BGI (2020b). BGI Develops Real-time Fluorescent RT-PCR kit for Detecting the 2019 Novel Coronavirus. Available online at: https://www.bgi.com/us/company/ news/bgi-develops-real-time-dna-based-kit-for-detecting-the-2019-novelcoronavirus/ (accessed July 30, 2020).

BioMedomics (2020). COVID-19 IgM/IgG Rapid Test. Morrisville, NC: BioMedomics, Inc.

Biomeme (2020). Biomeme COVID-19 Go-Strips. Philadelphia, PA: Biomeme.

Blanco-Melo, D., Nilsson-Payant, B. E., Liu, W.-C., Uhl, S., Hoagland, D., Møller, R., et al. (2020). Imbalanced host response to SARS-CoV- drives development of COVID-19. Cell 181, 1036-1045.e9. doi: 10.1016/j.cell.2020.04.026

Boettler, T., Newsome, P. N., Mondelli, M. U., Maticic, M., Cordero, E., Cornberg, M., et al. (2020). Care of patients with liver disease during the COVID-19 pandemic: EASL-ESCMID position paper. JHEP Rep. 2:100113. doi: 10.1016/ j.jhepr.2020.100113

Boga, J. A., and Coto-Montes, A. (2020). ER stress and autophagy induced by SARS-CoV-2: the targets for melatonin treatment. Melatonin Res. 3, 346-361. doi: $10.32794 / \mathrm{mr} 11250067$

Boriskin, Y. S., Leneva, I. A., Pécheur, E.-I., and Polyak, S. J. (2008). Arbidol: a broad-spectrum antiviral compound that blocks viral fusion. Curr. Med. Chem. 15, 997-1005. doi: 10.2174/092986708784049658

Cai, Q., Yang, M., Liu, D., Chen, J., Shu, D., Xia, J., et al. (2020). Experimental treatment with favipiravir for COVID-19: an open-label control study. Engineering. doi: 10.1016/j.eng.2020.03.007

Cai, X.-F., Chen, J., Li Hu, J., Long, Q.-X., Deng, H.-J., Liu, P., et al. (2020). A peptide-based magnetic chemiluminescence enzyme immunoassay for serological diagnosis of corona virus disease 2019 (COVID-19). J. Infect. Dis. 222, 189-193. doi: 10.1093/infdis/jiaa243

Campos, E. V. R., de Oliveira, J. L., Abrantes, D. C., Rogério, C. B., Bueno, C., Miranda, V. R., et al. (2020). Recent developments in nanotechnology for detection and control of aedes aegypti-borne diseases. Front. Bioeng. Biotechnol. 8:102. doi: 10.3389/fbioe.2020.00102

Carmona-Gutierrez, D., Bauer, M. A., Zimmermann, A., Kainz, K., Hofer, S. J., Kroemer, G., et al. (2020). Digesting the crisis: autophagy and coroaviruses. Microb. Cell 7, 119-128. doi: 10.15698/mic2020.05.715

Carter, L. J., Garner, L. V., Smoot, J. W., Li, Y., Zhou, Q., Saveson, C. J., et al. (2020). Assay techniques and test development for COVID-19 diagnosis. ACS Cent. Sci. 6, 591-605. doi: 10.1021/acscentsci.0c00501

Cascella, M., Rajnik, M., Cuomo, A., Dulebohn, S. C., and Di Napoli, R. (2020). "Features, evaluation and treatment coronavirus (COVID-19)," in StatPearls, (Treasure Island, FL: StatPearls Publishing). Available online at: http://www. ncbi.nlm.nih.gov/books/NBK554776/ (accessed July 30, 2020).

CDCP (2020a). CDC 2019-Novel Coronavirus (2019- $n$ CoV) Real-Time RT-PCR Diagnostic Panel; Division of Viral Diseases, U.S. Atlanta, GA: Centers for Disease Control and Prevention (CDCP).

CDCP (2020b). Information for Laboratories About Coronavirus (COVID-19). Centers for Disease Control and Prevention. Available online at: https: //www.cdc.gov/coronavirus/2019-ncov/lab/virus-requests.html (accessed July $30,2020)$.
Cellex (2020). qSARS-CoV-2 IgG/IgM Rapid Test. Cellex Inc. Available online at: https://cellexcovid.com/product/ (accessed July 30, 2020).

Chen, G., Svirskis, D., Lu, W., Ying, M., Huang, Y., and Wen, J. (2018). $\mathrm{N}$-trimethyl chitosan nanoparticles and CSKSSDYQC peptide: N-trimethyl chitosan conjugates enhance the oral bioavailability of gemcitabine to treat breast cancer. J. Control Release 277, 142-153. doi: 10.1016/j.jconrel.2018.03. 013

Chen, X., Wang, K., Xing, Y., Tu, J., Yang, X., Zhao, Q., et al. (2014). Coronavirus membrane-associated papain-like proteases induce autophagy through interacting with Beclin1 to negatively regulate antiviral innate immunity. Protein Cell 5, 912-927. doi: 10.1007/s13238-014-0104-6

Chowdhury, A. D., Takemura, K., Li, T.-C., Suzuki, T., and Park, E. Y. (2019). Electrical pulse-induced electrochemical biosensor for hepatitis $\mathrm{E}$ virus detection. Nat. Commun. 10:3737. doi: 10.1038/s41467-019-11644-5

Christian, M. D., Poutanen, S. M., Loutfy, M. R., Muller, M. P., and Low, D. E. (2004). Severe acute respiratory syndrome. Clin. Infect. Dis. 38, 1420-1427. doi: $10.1086 / 420743$

Chu, C. M., Cheng, V. C. C., Hung, I. F. N., Wong, M. M. L., Chan, K. H., Chan, K. S., et al. (2004). Role of lopinavir/ritonavir in the treatment of SARS: initial virological and clinical findings. Thorax 59, 252-256. doi: 10.1136/thorax.2003. 012658

Chu, D. K. W., Pan, Y., Cheng, S. M. S., Hui, K. P. Y., Krishnan, P., Liu, Y., et al. (2020). Molecular diagnosis of a novel coronavirus (2019-nCoV) causing an outbreak of pneumonia. Clin. Chem. 66, 549-555. doi: 10.1093/clinchem/ hvaa029

Chu, H., Chan, J. F.-W., Wang, Y., Yuen, T. T.-T., Chai, Y., Hou, Y., et al. (2020). Comparative replication and immune activation profiles of SARS-CoV2 and SARS-CoV in human lungs: an ex vivo study with implications for the pathogenesis of COVID-19. Clin. Infect. Dis. 71, 1400-1409. doi: 10.1093/cid/ ciaa 410

Conti, P., Ronconi, G., Caraffa, A., Gallenga, C., Ross, R., Frydas, I., et al. (2020). Induction of pro-inflammatory cytokines (IL-1 and IL-6) and lung inflammation by Coronavirus-19 (COVI-19 or SARS-CoV-2): antiinflammatory strategies. J. Biol. Regul. Homeost. Agents 34, 327-331. doi: 10. 23812/CONTI-E

Corley, M. J., and Ndhlovu, L. C. (2020). DNA methylation analysis of the COVID19 host cell receptor, Angiotensin I converting enzyme 2 gene (ACE2) in the respiratory system reveal age and gender differences. Preprints. doi: 10.20944/ preprints202003.0295.v1

Corman, V. M., Landt, O., Kaiser, M., Molenkamp, R., Meijer, A., Chu, D. K., et al. (2020). Detection of 2019 novel coronavirus (2019-nCoV) by realtime RT-PCR. Euro. Surveill. 25:2000045. doi: 10.2807/1560-7917.ES.2020.25.3. 2000045

Cottam, E. M., Maier, H. J., Manifava, M., Vaux, L. C., Chandra-Schoenfelder, P., Gerner, W., et al. (2011). Coronavirus nsp6 proteins generate autophagosomes from the endoplasmic reticulum via an omegasome intermediate. Autophagy 7 , 1335-1347. doi: 10.4161/auto.7.11.16642

Coutard, B., Valle, C., de Lamballerie, X., Canard, B., Seidah, N. G., and Decroly, E. (2020). The spike glycoprotein of the new coronavirus 2019-nCoV contains a furin-like cleavage site absent in $\mathrm{CoV}$ of the same clade. Antiviral Res. 176:104742. doi: 10.1016/j.antiviral.2020.104742

Crasto, A. M. (2020). Approve drugs against Coronavirus. New Drug Approvals Available online at: https://newdrugapprovals.org/tag/coronavirus/ (accessed August 1, 2020),

de Souza, E., Silva, J. M., Hanchuk, T. D. M., Santos, M. I., Kobarg, J., Bajgelman, M. C., et al. (2016). Viral inhibition mechanism mediated by surface-modified silica nanoparticles. ACS Appl. Mater. Interfaces 8, 16564-16572. doi: 10.1021/ acsami.6b03342

Deng, X., Hackbart, M., Mettelman, R. C., O’Brien, A., Mielech, A. M., Yi, G., et al. (2017). Coronavirus nonstructural protein 15 mediates evasion of dsRNA sensors and limits apoptosis in macrophages. Proc. Natl. Acad. Sci. U.S.A. 114, E4251-E4260. doi: 10.1073/pnas.1618310114

Desai, S., Vatsa Mishra, S., Joshi, A., Sarkar, D., Hole, A., Mishra, R., et al. (2020). Raman spectroscopy based detection of RNA viruses in saliva: a preliminary report. J. Biophoton. doi: 10.1002/jbio.202000189

Dong, L., Hu, S., and Gao, J. (2020). Discovering drugs to treat coronavirus disease 2019 (COVID-19). Drug Discov. Ther. 14, 58-60. doi: 10.5582/ddt.2020.01012 
Du, Y.-X., and Chen, X.-P. (2020). Favipiravir: pharmacokinetics and concerns about clinical trials for 2019-nCoV Infection. Clin. Pharmacol. Ther. 108, 242-247. doi: 10.1002/cpt.1844

Eissa, S., Siaj, M., and Zourob, M. (2015). Aptamer-based competitive electrochemical biosensor for brevetoxin-2. Biosens. Bioelectron. 69, 148-154. doi: 10.1016/j.bios.2015.01.055

Elfiky, A. A. (2020). Ribavirin, remdesivir, sofosbuvir, galidesivir, and tenofovir against SARS-CoV-2 RNA dependent RNA polymerase (RdRp): a molecular docking study. Life Sci. 253:117592. doi: 10.1016/j.lfs.2020.117592

El-Hamid, H. S. A., Ellakany, H. F., Elbestawy, A. R., Seliem, A. A., and Khalil, H. S. (2018). In vitro antiviral activity of commercial products of herbal extracts against highly pathogenic avian influenza (H5N1) virus. Alexand. J. Vet. Sci. 56, 145-152. doi: 10.5455/ajvs.281430

Eyer, L., Nougairède, A., Uhlíøová, M., Driouich, J.-S., Zouharová, D., Valdés, J. J., et al. (2019). An E460D substitution in the NS5 protein of tick-borne encephalitis virus confers resistance to the inhibitor Galidesivir (BCX4430) and also attenuates the virus for mice. J. Virol. 93:e00367-19. doi: 10.1128/JVI. 00367-19

Fandiño, J., Vaz, A. A., Toba, L., Romaní-Pérez, M., González-Matías, L., Mallo, F., et al. (2018). Liraglutide enhance the activity of the ACE-2/Ang(1-7)/ mas receptor pathway in lungs of male pups from food-restricted mothers and prevents the reduction of Sp-A. Int. J. Endocrinol. 2018:6920620. doi: 10.1155/ 2018/6920620

Fatin, M. F., Rahim Ruslinda, A., Gopinath, S. C. B., Arshad, M. K. M., Hashim, U., Lakshmipriya, T., et al. (2019). Co-ordinated split aptamer assembly and disassembly on Gold nanoparticle for functional detection of HIV-1 tat. Process. Biochem. 79, 32-39. doi: 10.1016/j.procbio.2018.12.016

Fehr, A. R., and Perlman, S. (2015). Coronaviruses: an overview of their replication and pathogenesis. Coronaviruses 1282, 1-23. doi: 10.1007/978-1-4939-24 38-7_1

Freundt, E. C., Yu, L., Goldsmith, C. S., Welsh, S., Cheng, A., Yount, B., et al. (2010). The open reading frame $3 \mathrm{a}$ protein of severe acute respiratory syndromeassociated coronavirus promotes membrane rearrangement and cell death. J. Virol. 84, 1097-1109. doi: 10.1128/JVI.01662-09

Fukushi, M., Yoshinaka, Y., Matsuoka, Y., Hatakeyama, S., Ishizaka, Y., Kirikae, T., et al. (2012). Monitoring of S protein maturation in the endoplasmic reticulum by calnexin is important for the infectivity of severe acute respiratory syndrome coronavirus. J. Virol. 86, 11745-11753. doi: 10.1128/JVI.012 50-12

Fung, S.-Y., Yuen, K.-S., Ye, Z.-W., Chan, C.-P., and Jin, D.-Y. (2020). A tugof-war between severe acute respiratory syndrome coronavirus 2 and host antiviral defence: lessons from other pathogenic viruses. Emerg. Microbes Infect. 9, 558-570. doi: 10.1080/22221751.2020.1736644

Fung, T. S., and Liu, D. X. (2014). Coronavirus infection, ER stress, apoptosis and innate immunity. Front. Microbiol. 5:296. doi: 10.3389/fmicb.2014.00296

Galluzzi, L., Diotallevi, A., and Magnani, M. (2017). Endoplasmic reticulum stress and unfolded protein response in infection by intracellular parasites. Future Sci. OA 3:FSO198. doi: 10.4155/fsoa-2017-0020

Gao, M., Yang, L., Chen, X., Deng, Y., Yang, S., Xu, H., et al. (2020). A study on infectivity of asymptomatic SARS-CoV-2 carriers. Respir. Med. 169:106026. doi: 10.1016/j.rmed.2020.106026

Goode, J. A., Rushworth, J. V. H., and Millner, P. A. (2015). Biosensor regeneration: a review of common techniques and outcomes. Langmuir 31, 6267-6276. doi: 10.1021/la503533g

Gordon, C. J., Tchesnokov, E. P., Feng, J. Y., Porter, D. P., and Götte, M. (2020). The antiviral compound remdesivir potently inhibits RNA-dependent RNA polymerase from Middle East respiratory syndrome coronavirus. J. Biol. Chem. 295, 4773-4779. doi: 10.1074/jbc.AC120.013056

Green, K., Winter, A., Dickinson, R., Graziadio, S., Wolff, R., Mallett, S., et al. (2020). What Tests Could Potentially be Used for the Screening, Diagnosis and Monitoring of COVID-19 and What are Their Advantages and Disadvantages? The Centre for Evidence Based Medicine (CEBM). CEBM. Available online at: https://www.cebm.net/covid-19/what-tests-could-potentially-be- used-forthe-screening-diagnosis-and-monitoring-of-covid-19-and-what-are-theiradvantages-and-disadvantages/ (accessed July 30, 2020).

Guo, G., Ye, L., Pan, K., Chen, Y., Xing, D., Yan, K., et al. (2020). New insights of emerging SARS-CoV-2: epidemiology, etiology, clinical features, clinical treatment, and prevention. Front. Cell Dev. Biol. 8:410. doi: 10.3389/fcell.2020. 00410

Guo, Y.-R., Cao, Q.-D., Hong, Z.-S., Tan, Y.-Y., Chen, S.-D., Jin, H.-J., et al. (2020). The origin, transmission and clinical therapies on coronavirus disease 2019 (COVID-19) outbreak - an update on the status. Mil. Med. Res. 7:11. doi: 10.1186/s40779-020-00240-0

Hamdy, M. E., Del Carlo, M., Hussein, H. A., Salah, T. A., El-Deeb, A. H., Emara, M. M., et al. (2018). Development of gold nanoparticles biosensor for ultrasensitive diagnosis of foot and mouth disease virus. J. Nanobiotechnol. 16:48. doi: 10.1186/s12951-018-0374-x

Harrison, C. (2020). Coronavirus puts drug repurposing on the fast track. Nat. Biotechnol. 38, 379-381. doi: 10.1038/d41587-020-00003-1

Hoffmann, M., Kleine-Weber, H., Schroeder, S., Krüger, N., Herrler, T., Erichsen, S., et al. (2020). SARS-CoV-2 cell entry depends on ACE2 and TMPRSS2 and is blocked by a clinically proven protease inhibitor. Cell 181, 271-280.e8. doi: 10.1016/j.cell.2020.02.052

Holshue, M. L., DeBolt, C., Lindquist, S., Lofy, K. H., Wiesman, J., Bruce, H., et al. (2020). First case of 2019 novel coronavirus in the United States. N. Engl. J. Med. 382, 929-936. doi: 10.1056/NEJMoa2001191

Hu, T. Y., Frieman, M., and Wolfram, J. (2020). Insights from nanomedicine into chloroquine efficacy against COVID-19. Nat. Nanotechnol. 15, 247-249. doi: 10.1038/s41565-020-0674-9

Huang, C., Wang, Y., Li, X., Ren, L., Zhao, J., Hu, Y., et al. (2020). Clinical features of patients infected with 2019 novel coronavirus in Wuhan, China. Lancet 395, 497-506. doi: 10.1016/S0140-6736(20)30183-5

Huang, L., Zhang, L., Liu, Y., Luo, R., Zeng, L., Telegina, I., et al. (2017). Arbidol for preventing and treating influenza in adults and children. Cochr. Database Syst. Rev. 2017:CD011489. doi: 10.1002/14651858.CD011489.pub2

Iftikhar, H., Ali, H. N., Farooq, S., Naveed, H., and Shahzad-Ul-Hussan, S. (2020). Identification of potential inhibitors of three key enzymes of SARS-CoV2 using computational approach. Comput. Biol. Med. 122:103848. doi: 10.1016/ j.compbiomed.2020.103848

Inan, H., Wang, S., Inci, F., Baday, M., Zangar, R., Kesiraju, S., et al. (2017). Isolation, detection, and quantification of cancer biomarkers in HPV-associated malignancies. Sci. Rep. 7:3322. doi: 10.1038/s41598-017-02672-6

Islam, S., Shukla, S., Bajpai, V. K., Han, Y.-K., Huh, Y. S., Kumar, A., et al. (2019). A smart nanosensor for the detection of human immunodeficiency virus and associated cardiovascular and arthritis diseases using functionalized graphenebased transistors. Biosens. Bioelectron. 126, 792-799. doi: 10.1016/j.bios.2018. 11.041

Jacobi, L., Damle, V. H., Rajeswaran, B., and Tischler, Y. R. (2020). Lowfrequency raman spectroscopy as a diagnostic tool for COVID-19 and other coronaviruses. R. Soc. Open Sci. 7, 1-28. doi: 10.17605/OSF.IO/ $\mathrm{Y} 54 \mathrm{H} 3$

Jazayeri, M. H., Aghaie, T., Avan, A., Vatankhah, A., and Ghaffari, M. R. S. (2018). Colorimetric detection based on gold nano particles (GNPs): An easy, fast, inexpensive, low-cost and short time method in detection of analytes (protein. DNA, and ion). Sens. Biosens. Res. 20, 1-8. doi: 10.1016/j.sbsr.2018.05.002

Jena, A. B., Kanungo, N., Nayak, V., Chainy, G. B. N., and Dandapat, J. (2020). Catechin and curcumin interact with corona (2019-nCoV/SARS-CoV2) viral $S$ protein and ACE2 of human cell membrane: insights from Computational study and implication for intervention. Res. Square doi: 10.21203/rs.3.rs-22057/ v1

Kapuy, O., Vinod, P. K., and Bánhegyi, G. (2014). mTOR inhibition increases cell viability via autophagy induction during endoplasmic reticulum stress - an experimental and modeling study. FEBS Open Bio. 4, 704-713. doi: 10.1016/j. fob.2014.07.006

Kerry, R. G., Malik, S., Redda, Y. T., Sahoo, S., Patra, J. K., and Majhi, S. (2019). Nano-based approach to combat emerging viral (NIPAH virus) infection. Nanomedicine 18, 196-220. doi: 10.1016/j.nano.2019.03.004

Kerry, R. G., Shin, H.-S., Gouda, S., Sahoo, S., Das, G., Fraceto, L. F., et al. (2018). Current advances in nanocarriers for biomedical research and their applications. Artif. Cells Nanomed. Biotechnol. 46, 1053-1062. doi: 10.1080/ 21691401.2018.1478843

Khalili, J. S., Zhu, H., Mak, N. S. A., Yan, Y., and Zhu, Y. (2020). Novel coronavirus treatment with ribavirin: groundwork for an evaluation concerning COVID-19. J. Med. Virol. 92, 740-746. doi: 10.1002/jmv.25798 
Khan, R. S., and Rehman, I. U. (2020). Spectroscopy as a tool for detection and monitoring of Coronavirus (COVID-19). Expert Rev. Mol. Diagn. 20, 1-3. doi: 10.1080/14737159.2020.1766968

Kim, Y., Jedrzejczak, R., Maltseva, N. I., Wilamowski, M., Endres, M., Godzik, A., et al. (2020). Crystal structure of Nsp15 endoribonuclease NendoU from SARS-CoV-2. Protein Sci. 29, 1596-1605. doi: 10.1002/pro.3873

Kondel, R., Shafiq, N., Kaur, I. P., Singh, M. P., Pandey, A. K., Ratho, R. K., et al. (2019). Effect of acyclovir solid lipid nanoparticles for the treatment of herpes simplex virus (HSV) infection in an animal model of HSV-1 infection. Pharm. Nanotechnol. 7, 389-403. doi: 10.2174/2211738507666190829161737

Konno, Y., Kimura, I., Uriu, K., Fukushi, M., Irie, T., Koyanagi, Y., et al. (2020). SARS-CoV-2 ORF3b is a potent interferon antagonist whose activity is further increased by a naturally occurring elongation variant. bioRxiv [Preprint]. doi: 10.1101/2020.05.11.088179 bioRxiv: 2020.05.11.088179.

Krähling, V., Stein, D. A., Spiegel, M., Weber, F., and Mühlberger, E. (2009). Severe acute respiratory syndrome coronavirus triggers apoptosis via protein kinase $\mathrm{R}$ but is resistant to its antiviral activity. J. Virol. 83, 2298-2309. doi: 10.1128/JVI.01245-08

Lai, H. C., Chin, S. F., Pang, S. C., Henry Sum, M. S., and Perera, D. (2017). Carbon nanoparticles based electrochemical biosensor strip for detection of japanese encephalitis virus. J. Nanomat. 2017:e3615707. doi: 10.1155/2017/3615707

Lauer, S. A., Grantz, K. H., Bi, Q., Jones, F. K., Zheng, Q., Meredith, H. R., et al. (2020). The incubation period of coronavirus disease 2019 (COVID-19) from publicly reported confirmed cases: Estimation and application. Ann. Intern. Med. 172, 577-582. doi: 10.7326/M20-0504

Lauri, A., and Mariani, P. O. (2009). Potentials and limitations of molecular diagnostic methods in food safety. Genes Nutr. 4, 1-12. doi: 10.1007/s12263008-0106-1

Lauster, D., Klenk, S., Ludwig, K., Nojoumi, S., Behren, S., Adam, L., et al. (2020). Phage capsid nanoparticles with defined ligand arrangement block influenza virus entry. Nat. Nanotechnol. 15, 373-379. doi: 10.1038/s41565-020-0660-2

Lee, E. C., Davis-Poynter, N., Nguyen, C. T. H., Peters, A. A., Monteith, G. R., Strounina, E., et al. (2016). GAG mimetic functionalised solid and mesoporous silica nanoparticles as viral entry inhibitors of herpes simplex type 1 and type 2 viruses. Nanoscale 8, 16192-16196. doi: 10.1039/c6nr03878f

Lee, J.-H., Oh, B.-K., and Choi, J.-W. (2013). Electrochemical sensor based on direct electron transfer of HIV-1 virus at Au nanoparticle modified ITO electrode. Biosens. Bioelectron. 49, 531-535. doi: 10.1016/j.bios.2013.06.010

Lemmer, H. J. R., and Liebenberg, W. (2013). Preparation and evaluation of metastable solid-state forms of lopinavir. Pharmazie 68, 327-332. doi: 10.1691/ ph.2013.2194

Letko, M., Marzi, A., and Munster, V. (2020). Functional assessment of cell entry and receptor usage for SARS-CoV-2 and other lineage B betacoronaviruses. Nat. Microbiol. 5, 562-569. doi: 10.1038/s41564-020-0688-y

Liu, C., Zhou, Q., Li, Y., Garner, L. V., Watkins, S. P., Carter, L. J., et al. (2020). Research and development on therapeutic agents and vaccines for COVID19 and related human coronavirus diseases. ACS Cent. Sci. 6, 315-331. doi: 10.1021/acscentsci.0c00272

Loustaud-Ratti, V., Debette-Gratien, M., Jacques, J., Alain, S., Marquet, P., Sautereau, D., et al. (2016). Ribavirin: past, present and future. World J. Hepatol. 8, 123-130. doi: 10.4254/wjh.v8.i2.123

Lukassen, S., Chua, R. L., Trefzer, T., Kahn, N. C., Schneider, M. A., Muley, T., et al. (2020). SARS-CoV-2 receptor ACE2 and TMPRSS2 are primarily expressed in bronchial transient secretory cells. EMBO J. 39:e105114. doi: 10.15252/embj. 20105114

Lung, J., Lin, Y.-S., Yang, Y.-H., Chou, Y.-L., Shu, L.-H., Cheng, Y.-C., et al. (2020). The potential chemical structure of anti-SARS-CoV-2 RNA-dependent RNA polymerase. J. Med. Virol. 92, 693-697. doi: 10.1002/jmv.25761

Maier, H. J., and Britton, P. (2012). Involvement of autophagy in coronavirus replication. Viruses 4, 3440-3451. doi: 10.3390/v4123440

Mahdian, S., Zarrabi, M., Moini, A., Movahedi, M., and Shahhoseini, M. (2020). In silico identification of new inhibitors for ßeta-2-glycoprotein I as a major antigen in antiphospholipid antibody syndrome. J. Mol. Model. 26, 156. doi: 10.1007/s00894-020-04406-4

Mangan, M. S. J., Olhava, E. J., Roush, W. R., Seidel, H. M., Glick, G. D., and Latz, E. (2018). Targeting the NLRP3 inflammasome in inflammatory diseases. Nat. Rev. Drug. Discov. 17, 588-606. doi: 10.1038/nrd.2018.97
Matsuyama, S., Nao, N., Shirato, K., Kawase, M., Saito, S., Takayama, I., et al. (2020). Enhanced isolation of SARS-CoV-2 by TMPRSS2-expressing cells. Proc. Natl. Acad. Sci. U.S.A. 117, 7001-7003. doi: 10.1073/pnas.2002589117

McCreary, E. K., and Pogue, J. M. (2020). Coronavirus disease 2019 treatment: a review of early and emerging options. Open Forum. Infect. Dis. 7:ofaa105. doi: 10.1093/ofid/ofaa105

Mirza, M. U., and Froeyen, M. (2020). Structural elucidation of SARS-CoV-2 vital proteins: computational methods reveal potential drug candidates against main protease, Nsp12 polymerase and Nsp13 helicase. J. Pharm. Anal. 10, 320-328. doi: 10.1016/j.jpha.2020.04.008

Mishra, S., Pandey, A., and Manvati, S. (2020). Coumarin: an emerging antiviral agent. Heliyon 6:e03217. doi: 10.1016/j.heliyon.2020.e03217

Mohammadi Pour, P., Fakhri, S., Asgary, S., Farzaei, M. H., and Echeverría, J. (2019). The signaling pathways, and therapeutic targets of antiviral agents: focusing on the antiviral approaches and clinical perspectives of anthocyanins in the management of viral diseases. Front. Pharmacol. 10:1207. doi: 10.3389/ fphar.2019.01207

Moitra, P., Alafeef, M., Dighe, K., Frieman, M. B., and Pan, D. (2020). Selective naked-eye detection of SARS-CoV-2 mediated by $\mathrm{N}$ gene targeted antisense oligonucleotide capped plasmonic nanoparticles. ACS Nano 14, 7617-7627. doi: 10.1021/acsnano.0c03822

Mu, J., Xu, J., Zhang, L., Shu, T., Wu, D., Huang, M., et al. (2020). SARS-CoV-2encoded nucleocapsid protein acts as a viral suppressor of RNA interference in cells. Sci. China Life Sci. 63, 1-4. doi: 10.1007/s11427-020-1692-1

Mueller, A. L., McNamara, M. S., and Sinclair, D. A. (2020). Why does COVID19 disproportionately affect older people? Aging 12, 9959-9981. doi: 10.18632/ aging.103344

Mylab (2020). PathoDetect CoVID-19 Detection Kit. Pune: Mylab Discovery Solutions Pvt. Ltd.

Nal, B., Chan, C., Kien, F., Siu, L., Tse, J., Chu, K., et al. (2005). Differential maturation and subcellular localization of severe acute respiratory syndrome coronavirus surface proteins S. M and E. J. Gen. Virol. 86, 1423-1434. doi: 10.1099/vir.0.80671-0

Nao, N., Shirato, K., Katano, H., Matsuyama, S., and Takeda, M. (2020). Detection of Second case of 2019-nCoV Infection in Japan, National Institute of Infectious Diseases (NIID), Japan. National Institute of Infectious Diseases. Available online at: https://www.niid.go.jp/niid/en/2019-ncov-e/9334-ncov-vir3-2.html (accessed July 30, 2020)

Natesan, M., Wu, S.-W., Chen, C.-I., Jensen, S. M. R., Karlovac, N., Dyas, B. K., et al. (2019). A smartphone-based rapid telemonitoring system for ebola and marburg disease surveillance. ACS Sens. 4, 61-68. doi: 10.1021/acssensors. 8 b00842

Nieto-Torres, J. L., Verdiá-Báguena, C., Jimenez-Guardeño, J. M., Regla-Nava, J. A., Castaño-Rodriguez, C., Fernandez-Delgado, R., et al. (2015). Severe acute respiratory syndrome coronavirus E protein transports calcium ions and activates the NLRP3 inflammasome. Virology 485, 330-339. doi: 10.1016/j.virol. 2015.08.010

NIH (2020). A Study to Evaluate the Safety, Pharmacokinetics and Antiviral Effects of Galidesivir in Yellow Fever or COVID-19, US. National Institute of Health. Available online at: https://clinicaltrials.gov/ct2/show/NCT03891420 (accessed August 1, 2020).

Noh, G. (2020). Ifn-Gamma as a major antiviral therapeutic for viral epidemics, including severe acute respiratory syndrome coronavirus 2 (SARS-CoV-2): a clinically forgotten but potential antiviral cytokine and non-virus-specific antiviral as a new antiviral strategy. J. Clin. Rev. Case Rep. 5, 1-5. doi: 10.33140/ JCRC

Ou, X., Liu, Y., Lei, X., Li, P., Mi, D., Ren, L., et al. (2020). Characterization of spike glycoprotein of SARS-CoV-2 on virus entry and its immune cross-reactivity with SARS-CoV. Nat. Commun. 11:1620. doi: 10.1038/s41467-020-15562-9

Pala, R., Mohieldin, A. M., Shamloo, K., Sherpa, R. T., Kathem, S. H., Zhou, J., et al. (2019). Personalized nanotherapy by specifically targeting cell organelles to improve vascular hypertension. Nano Lett. 19, 904-914. doi: 10.1021/acs. nanolett.8b04138

Pan, L., He, Q., Liu, J., Chen, Y., Ma, M., Zhang, L., et al. (2012). Nucleartargeted drug delivery of TAT peptide-conjugated monodisperse mesoporous silica nanoparticles. J. Am. Chem. Soc. 134, 5722-5725. doi: 10.1021/ja21 $1035 \mathrm{w}$ 
Pang, J., Wang, M. X., Ang, I. Y. H., Tan, S. H. X., Lewis, R. F., Chen, J. I.-P., et al. (2020). Potential rapid diagnostics, vaccine and therapeutics for 2019 novel coronavirus (2019-nCoV): a systematic review. J. Clin. Med. 9:623. doi: $10.3390 /$ jcm 9030623

Panigrahi, B., Singh, R. K., Mishra, S., and Mandal, D. (2018). Cyclic peptide-based nanostructures as efficient siRNA carriers. Artif. Cells Nanomed. Biotechnol. 46, S763-S773. doi: 10.1080/21691401.2018.1511574

Park, A., and Iwasaki, A. (2020). Type I and Type III interferons-inuction, signaling, evasion, and application to combat COVID-19. Cell Host Microbe 27, 870-878. doi: 10.1016/j.chom.2020.05.008

Petrakis, D., Marginǎ, D., Tsarouhas, K., Tekos, F., Stan, M., Nikitovic, D., et al. (2020). Obesity - a risk factor for increased COVID-19 prevalence, severity and lethality (Review). Mol. Med. Rep. 22, 9-19. doi: 10.3892/mmr.2020.11127

Poppe, M., Wittig, S., Jurida, L., Bartkuhn, M., Wilhelm, J., Müller, H., et al. (2017). The NF-кB-dependent and -independent transcriptome and chromatin landscapes of human coronavirus 229E-infected cells. PLoS Pathog. 13:e1006286. doi: 10.1371/journal.ppat.1006286

Prentice, E., Jerome, W. G., Yoshimori, T., Mizushima, N., and Denison, M. R. (2004a). Coronavirus replication complex formation utilizes components of cellular autophagy. J. Biol. Chem. 279, 10136-10141. doi: 10.1074/jbc. M306124200

Prentice, E., McAuliffe, J., Lu, X., Subbarao, K., and Denison, M. R. (2004b). Identification and characterization of severe acute respiratory syndrome coronavirus replicase proteins. J. Virol. 78, 9977-9986. doi: 10.1128/JVI.78.18. 9977-9986.2004

Primerdesign (2020). COVID-19 Genesig ${ }^{\circledR}$ Real-Time PCR Assay. Southampton: Primer design Ltd.

Pruimboom, L. (2020). Methylation pathways and SARS-CoV-2 lung infiltration and cell membrane-virus fusion are both subject to epigenetics. Front. Cell Infect. Microbiol. 10:290. doi: 10.3389/fcimb.2020.00290

Ragel, B., and Jensen, R. L. (2003). New approaches for the treatment of refractory meningiomas. Cancer Control. 10, 148-158. doi: 10.1177/107327480301000206

Rashid, H.-O., Yadav, R. K., Kim, H.-R., and Chae, H.-J. (2015). ER stress: autophagy induction, inhibition and selection. Autophagy 11, 1956-1977. doi: 10.1080/15548627.2015.1091141

Reggiori, F., Monastyrska, I., Verheije, M. H., Calì, T., Ulasli, M., Bianchi, S., et al. (2010). Coronaviruses hijack the LC3-I-positive EDEMosomes, ERderived vesicles exporting short-lived ERAD regulators, for replication. Cell Host Microbe 7, 500-508. doi: 10.1016/j.chom.2010.05.013

Richardson, P., Griffin, I., Tucker, C., Smith, D., Oechsle, O., Phelan, A., et al. (2020). Baricitinib as potential treatment for 2019-nCoV acute respiratory disease. Lancet 395, e30-e31. doi: 10.1016/S0140-6736(20)30304-4

Roche (2020). Tib-Molbiol's 2019-nCoV Real-time RT-PCR kit. Tib Molbiol, Roche Diagnostics, Spain. Available online at: https://www.roche-as.es/noticias (accessed July 30, 2020).

Rossignol, J.-F. (2014). Nitazoxanide: a first-in-class broad-spectrum antiviral agent. Antiviral Res. 110, 94-103. doi: 10.1016/j.antiviral.2014.07.014

Rossignol, J.-F. (2016). Nitazoxanide, a new drug candidate for the treatment of Middle East respiratory syndrome coronavirus. J. Infect. Public Health 9 , 227-230. doi: 10.1016/j.jiph.2016.04.001

Rozières, A., Viret, C., and Faure, M. (2017). Autophagy in measles virus infection. Viruses 9:359. doi: 10.3390/v9120359

Sahin, A. R., Erdogan, A., Mutlu Agaoglu, P., Dineri, Y., Cakirci, A. Y., Senel, M. E., et al. (2020). 2019 novel Coronavirus (COVID-19) outbreak: a review of the current literature. Eurasian J. Med. Oncol. 4, 1-7. doi: 10.14744/ejmo.2020. 12220

Sallard, E., Lescure, F.-X., Yazdanpanah, Y., Mentre, F., and Peiffer-Smadja, N. (2020). Type 1 interferons as a potential treatment against COVID-19. Antiviral Res. 178, 104791. doi: 10.1016/j.antiviral.2020.104791

Sawalha, A. H., Zhao, M., Coit, P., and Lu, Q. (2020). Epigenetic dysregulation of ACE2 and interferon-regulated genes might suggest increased COVID-19 susceptibility and severity in lupus patients. Clin. Immunol. 215:108410. doi: 10.1016/j.clim.2020.108410

Saylan, Y., Erdem, Ö, Ünal, S., and Denizli, A. (2019). An alternative medical diagnosis method: biosensors for virus detection. Biosensors 9:65. doi: 10.3390/ bios 9020065

Saylan, Y., Y $ı$ lmaz, F., Derazshamshir, A., Y $\imath$ lmaz, E., and Denizli, A. (2017). Synthesis of hydrophobic nanoparticles for real-time lysozyme detection using surface plasmon resonance sensor. J. Mol. Recognit. 30:e2631. doi: 10.1002/jmr. 2631

Saylan, Y., Y $\imath$ lmaz, F., Özgür, E., Derazshamshir, A., Bereli, N., Yavuz, H., et al. (2018). "Surface plasmon resonance sensors for medical diagnosis," in Nanotechnology Characterization Tools for Biosensing and Medical Diagnosis, ed. C. S. S. R. Kumar (Berlin: Springer), 425-458. doi: 10.1007/978-3-66256333-5_10

Schafer, A., and Baric, R. S. (2017). Epigenetic landscape during coronavirus infection. Pathogens 6:8. doi: 10.3390/pathogens6010008

Schneider, M., Ackermann, K., Stuart, M., Wex, C., Protzer, U., Schätzl, H. M., et al. (2012). Severe acute respiratory syndrome coronavirus replication is severely impaired by MG132 due to proteasome-independent inhibition of M-calpain. J. Virol. 86, 10112-10122. doi: 10.1128/JVI.01001-12

Shah, A. (2020). Novel Coronavirus-Induced NLRP3 inflammasome activation: a potential drug target in the treatment of COVID-19. Front. Immunol. 11:1021. doi: $10.3389 /$ fimmu.2020.01021

Shamsi, A., Mohammad, T., Anwar, S., AlAjmi, M. F., Hussain, A., Rehman, M. T., et al. (2020). Glecaprevir and maraviroc are high-affinity inhibitors of SARSCoV-2 main protease: possible implication in COVID-19 therapy. Biosci. Rep. 40:BSR20201256. doi: 10.1042/BSR20201256

Sheridan, C. (2020). Coronavirus and the race to distribute reliable diagnostics. Nat. Biotechnol. 38, 382-384. doi: 10.1038/d41587-020-00002-2

Shi, C.-S., Nabar, N. R., Huang, N.-N., and Kehrl, J. H. (2019). SARS-Coronavirus open reading frame-8b triggers intracellular stress pathways and activates NLRP3 inflammasomes. Cell Death Discov. 5:101. doi: 10.1038/s41420-0190181-7

Shiraki, K., and Daikoku, T. (2020). Favipiravir, an anti-influenza drug against lifethreatening RNA virus infections. Pharmacol. Ther. 209:107512. doi: 10.1016/j. pharmthera.2020.107512

Shojaei, S., Suresh, M., Klionsky, D. J., Labouta, H. I., and Ghavami, S. (2020). Autophagy and SARS-CoV-2 infection: apossible smart targeting of the autophagy pathway. Virulence 11, 805-810. doi: 10.1080/21505594.2020. 1780088

Siu, K.-L., Yuen, K.-S., Castaño-Rodriguez, C., Ye, Z.-W., Yeung, M.-L., Fung, S.-Y., et al. (2019). Severe acute respiratory syndrome coronavirus ORF3a protein activates the NLRP3 inflammasome by promoting TRAF3-dependent ubiquitination of ASC. FASEB J. 33, 8865-8877. doi: 10.1096/fj.201802 $418 \mathrm{R}$

Smits, S. L., de Lang, A., van den Brand, J. M. A., Leijten, L. M., van IJcken, W. F., Eijkemans, M. J. C., et al. (2010). Exacerbated innate host response to SARS-CoV in aged non-human primates. PLoS Pathog. 6:e1000756. doi: 10.1371/journal.ppat.1000756

Snijder, E. J., van der Meer, Y., Zevenhoven-Dobbe, J., Onderwater, J. J. M., van der Meulen, J., Koerten, H. K., et al. (2006). Ultrastructure and origin of membrane vesicles associated with the severe acute respiratory syndrome coronavirus replication complex. J. Virol. 80, 5927-5940. doi: 10.1128/JVI.025 01-05

Song, F., Shi, N., Shan, F., Zhang, Z., Shen, J., Lu, H., et al. (2020). Emerging 2019 Novel Coronavirus (2019-nCoV) pneumonia. Radiology 295, 210-217. doi: 10.1148/radiol.2020200274

Song, Z., Wang, X., Zhu, G., Nian, Q., Zhou, H., Yang, D., et al. (2015). Virus capture and destruction by label-free graphene oxide for detection and disinfection applications. Small 11, 1171-1176. doi: 10.1002/smll.20140 1706

Stebbing, J., Phelan, A., Griffin, I., Tucker, C., Oechsle, O., Smith, D., et al. (2020). COVID-19: combining antiviral and anti-inflammatory treatments. Lancet Infect. Dis. 20, 400-402. doi: 10.1016/S1473-3099(20)30132-8

Sureda, A., Alizadeh, J., Nabavi, S. F., Berindan-Neagoe, I., Cismaru, C. A., Jeandet, P., et al. (2020). Endoplasmic reticulum as a potential therapeutic target for covid-19 infection management? Eur. J. Pharmacol. 882:173288. doi: 10.1016/ j.ejphar. 2020.173288

Tang, B. S. F., Chan, K. H., Cheng, V. C. C., and Yuen, K. Y. (2009). Comparative host gene transcription by microarray analysis early after infection of the Huh7 cell line by SARS coronavirus and human coronavirus 229E. Hong Kong Med. J. 15(Suppl. 9), 23-26.

Tay, M. Z., Poh, C. M., Rénia, L., MacAry, P. A., and Ng, L. F. P. (2020). The trinity of COVID-19: immunity, inflammation and intervention. Nat. Rev. Immunol. 20, 363-374. doi: 10.1038/s41577-020-0311-8 
ThermoFisher (2020). TaqMan ${ }^{T M} 2019-n$ CoV Control Kit v1 for Pathogen Detection of SARS-CoV-2 RNA. Waltham, MA: Thermo Fisher Scientific.

Tikellis, C., and Thomas, M. C. (2012). Angiotensin-converting enzyme 2 (ACE2) is a key modulator of the renin angiotensin system in health and disease. Int. J. Pept. 2012:256294. doi: 10.1155/2012/256294

Ton, A.-T., Gentile, F., Hsing, M., Ban, F., and Cherkasov, A. (2020). Rapid identification of potential inhibitors of SARS-CoV-2 main protease by deep docking of 1.3 billion compounds. Mol. Inform. 39:e2000028. doi: 10.1002/minf. 202000028

Totura, A. L., and Baric, R. S. (2012). SARS coronavirus pathogenesis: host innate immune responses and viral antagonism of interferon. Curr. Opin. Virol. 2, 264-275. doi: 10.1016/j.coviro.2012.04.004

TRUPCR (2020). TRUPCR ${ }^{\circledR}$ SARS-CoV-2 RT qPCR Kit. 3B BlackBio Biotech India Ltd, India. Available online at: https://3bblackbio.com/covid-19corona-virus-real-time- qpcr-kit-sars-cov-2-trupcr.html (accessed July 30, 2020).

Udugama, B., Kadhiresan, P., Kozlowski, H. N., Malekjahani, A., Osborne, M., Li, V. Y. C., et al. (2020). Diagnosing COVID-19: the disease and tools for detection. ACS Nano 14, 3822-3835. doi: 10.1021/acsnano.0c02624

ul Qamar, M. T., Alqahtani, S. M., Alamri, M. A., and Chen, L.-L. (2020). Structural basis of SARS-CoV-2 3CLpro and anti-COVID-19 drug discovery from medicinal plants. J. Pharm. Anal. 10, 313-319. doi: 10.1016/j.jpha.2020. 03.009

Urio, L. J., Mohamed, M. A., Mghamba, J., Abade, A., and Aboud, S. (2015). Evaluation of HIV antigen/antibody combination ELISAs for diagnosis of HIV infection in Dar Es Salaam. Tanzania. Pan. Afr. Med. J. 20:196. doi: 10.11604/ pamj.2015.20.196.4934

Vaculovicova, M., Michalek, P., Krizkova, S., Macka, M., and Adam, V. (2017). Nanotechnology-based analytical approaches for detection of viruses. Anal. Methods 9, 2375-2391. doi: 10.1039/C7AY00048K

Veredus (2020). VereCoV ${ }^{T M}$ Detection Kit. Veredus Laboratories Pte Ltd. Available online at: https://vereduslabs.com/products/infectiousdiseases/verecov/ (accessed July 30, 2020).

Verma, N., and Bhardwaj, A. (2015). Biosensor technology for pesticides-a review. Appl. Biochem. Biotechnol. 175, 3093-3119. doi: 10.1007/s12010-015-1489-2

Vickers, N. J. (2017). Animal communication: when I'm calling you, will you answer too? Curr. Biol. 27, R713-R715. doi: 10.1016/j.cub.2017.05.064

Vincent, M. J., Bergeron, E., Benjannet, S., Erickson, B. R., Rollin, P. E., Ksiazek, T. G., et al. (2005). Chloroquine is a potent inhibitor of SARS coronavirus infection and spread. Virol. J. 2:69. doi: 10.1186/1743-422 $\mathrm{X}-2-69$

Wang, M., Cao, R., Zhang, L., Yang, X., Liu, J., Xu, M., et al. (2020). Remdesivir and chloroquine effectively inhibit the recently emerged novel coronavirus (2019-nCoV) in vitro. Cell Res. 30, 269-271. doi: 10.1038/s41422-020-0282-0

Wang, Q., Zhang, Y., Wu, L., Niu, S., Song, C., Zhang, Z., et al. (2020). Structural and functional basis of SARS-CoV-2 entry by using human ACE2. Cell 181, 894-904.e9. doi: 10.1016/j.cell.2020.03.045

Wang, W., Zhou, X., Bian, Y., Wang, S., Chai, Q., Guo, Z., et al. (2020). Dualtargeting nanoparticle vaccine elicits a therapeutic antibody response against chronic hepatitis B. Nat. Nanotechnol. 15, 406-416. doi: 10.1038/s41565-0200648-y

Wang, X., Zhou, Q., He, Y., Liu, L., Ma, X., Wei, X., et al. (2020). Nosocomial outbreak of COVID-19 pneumonia in Wuhan, China. Eur. Respir. J. 55:2000544. doi: 10.1183/13993003.00544-2020

Wang, Y., Liu, M., and Gao, J. (2020). Enhanced receptor binding of SARS-CoV2 through networks of hydrogen-bonding and hydrophobic interactions. Proc. Natl. Acad. Sci. U.S.A. 117, 13967-13974. doi: 10.1073/pnas.2008209117

Wang, Z., Wang, X., Li, M., Gao, Y., Hu, Z., Nan, T., et al. (2016). Highly sensitive flexible magnetic sensor based on anisotropic magnetoresistance effect. $A d v$. Mater. Weinheim. 28, 9370-9377. doi: 10.1002/adma.201602910

Weiss, C., Carriere, M., Fusco, L., Capua, I., Regla-Nava, J. A., Pasquali, M., et al. (2020). Toward nanotechnology-enabled approaches against the COVID-19 pandemic. ACS Nano 14, 6383-6406. doi: 10.1021/acsnano.0c03697

Wertheim, J. O., Chu, D. K. W., Peiris, J. S. M., Kosakovsky Pond, S. L., and Poon, L. L. M. (2013). A case for the ancient origin of coronaviruses. J. Virol. 87, 7039-7045. doi: 10.1128/JVI.03273-12

Westover, J. B., Mathis, A., Taylor, R., Wandersee, L., Bailey, K. W., Sefing, E. J., et al. (2018). Galidesivir limits Rift Valley fever virus infection and disease in
Syrian golden hamsters. Antiviral Res. 156, 38-45. doi: 10.1016/j.antiviral.2018. 05.013

WHO (2020a). Coronavirus Disease (COVID-19) Technical Guidance: Laboratory Testing for 2019-nCoV in Humans. Geneva: World Health Organization.

WHO (2020b). Detection of 2019 Novel Coronavirus (2019-nCoV) in Suspected Human Cases by RT-PCR. Geneva: World Health Organization.

WHO (2020c). Diagnostic Detection of Novel Coronavirus 2019 by Real Time RT-PCR. Department of Medical Sciences, Ministry of Public Health. Available online at: https://www.who.int/docs/default-source/coronaviruse/ conventional-rt-pcr-followed-by-sequencing-for-detection- of-ncov-rirl-natinst-health-t.pdf (accessed July 30, 2020).

WHO (2020d). WHO Director-General's opening remarks at the Media Briefing on COVID-19 - 11. Geneva: World Health Organization.

Winthrop, K. L. (2017). The emerging safety profile of JAK inhibitors in rheumatic disease. Nat. Rev. Rheumatol. 13, 234-243. doi: 10.1038/nrrheum.20 17.23

Wong, Y. K., Yang, J., and He, Y. (2020). Caution and clarity required in the use of chloroquine for COVID-19. Lancet Rheumatol. 2:e255. doi: 10.1016/S26659913(20)30093-X

Worldometer (2020). Coronavirus Update (Live): 17,242,728 Cases and 671,262 Deaths from COVID-19 Virus Pandemic. Worldometer. Available online at: https://www.worldometers.info/coronavirus/ (accessed August 2, 2020).

Wrapp, D., Wang, N., Corbett, K. S., Goldsmith, J. A., Hsieh, C.-L., Abiona, O., et al. (2020). Cryo-EM structure of the 2019-nCoV spike in the prefusion conformation. Science 367, 1260-1263. doi: 10.1126/science.abb2507

Wu, A., Peng, Y., Huang, B., Ding, X., Wang, X., Niu, P., et al. (2020). Genome composition and divergence of the novel coronavirus (2019-nCoV) originating in China. Cell Host Microbe 27, 325-328. doi: 10.1016/j.chom.2020.02.001

Wu, C., Liu, Y., Yang, Y., Zhang, P., Zhong, W., Wang, Y., et al. (2020). Analysis of therapeutic targets for SARS-CoV-2 and discovery of potential drugs by computational methods. Acta Pharm. Sin. B 10, 766-788. doi: 10.1016/j.apsb. 2020.02 .008

Xiang, J., Yan, M., Li, H., Liu, T., Lin, C., Huang, S., et al. (2020). Evaluation of enzyme-linked immunoassay and colloidal gold- immunochromatographic assay kit for detection of Novel Coronavirus (SARS-Cov-2) causing an outbreak of pneumonia (COVID-19). medRxiv [Preprint]. doi: 10.1101/2020.02.27. 20028787 medRxiv: 20028787.

Xiao, F., Tang, M., Zheng, X., Liu, Y., Li, X., and Shan, H. (2020). Evidence for gastrointestinal infection of SARS-CoV-2. Gastroenterology 158, 1831-1833.e3. doi: 10.1053/j.gastro.2020.02.055

Xu, H., Zhong, L., Deng, J., Peng, J., Dan, H., Zeng, X., et al. (2020). High expression of ACE2 receptor of 2019-nCoV on the epithelial cells of oral mucosa. Int. J. Oral Sci. 12:8. doi: 10.1038/s41368-020-0074-x

Yan, R., Zhang, Y., Li, Y., Xia, L., Guo, Y., and Zhou, Q. (2020). Structural basis for the recognition of SARS-CoV-2 by full-length human ACE2. Science 367, 1444-1448. doi: 10.1126/science.abb2762

Yang, H., Qi, D., Liu, Z., Chandran, B. K., Wang, T., Yu, J., et al. (2016). Soft thermal sensor with mechanical adaptability. Adv. Mater. Weinheim. 28, 9175-9181. doi: 10.1002/adma.201602994

Yang, N., and Shen, H.-M. (2020). Targeting the endocytic pathway and autophagyprocess as a novel therapeutic strategy in COVID-19. Int. J. Biol. Sci. 16, 1724-1731. doi: 10.7150/ijbs.45498

Yang, X. X., Li, C. M., Li, Y. F., Wang, J., and Huang, C. Z. (2017). Synergistic antiviral effect of curcumin functionalized graphene oxide against respiratory syncytial virus infection. Nanoscale 9, 16086-16092. doi: 10.1039/c7nr06 $520 \mathrm{e}$

Yap, J. K. Y., Moriyama, M., and Iwasaki, A. (2020). Inflammasomes and pyroptosis as therapeutic targets for COVID-19. J. Immunol. 205, 307-312. doi: 10.4049/ jimmunol.2000513

Yin, C. (2020). Genotyping coronavirus SARS-CoV-2: methods and implications. Genomics 112, 3588-3596. doi: 10.1016/j.ygeno.2020.04.016

Yorimitsu, T., Nair, U., Yang, Z., and Klionsky, D. J. (2006). Endoplasmic reticulum stress triggers autophagy. J. Biol. Chem. 281, 30299-30304. doi: 10.1074/jbc. M607007200

Yoshimoto, F. K. (2020). The proteins of severe acute respiratory syndrome coronavirus-2 (SARS CoV-2 or n-COV19), the cause of COVID-19. Protein J. 39, 198-216. doi: 10.1007/s10930-020-09901-4 
Zeldin, R. K., and Petruschke, R. A. (2004). Pharmacological and therapeutic properties of ritonavir-boosted protease inhibitor therapy in HIVinfected patients. J. Antimicrob. Chemother. 53, 4-9. doi: 10.1093/jac/ dkh029

Zhang, H., Penninger, J. M., Li, Y., Zhong, N., and Slutsky, A. S. (2020). Angiotensin-converting enzyme 2 (ACE2) as a SARS-CoV-2 receptor: molecular mechanisms and potential therapeutic target. Intensive Care Med. 46, 586-590. doi: 10.1007/s00134-020-05985-9

Zhang, W., Du, R.-H., Li, B., Zheng, X.-S., Yang, X.-L., Hu, B., et al. (2020). Molecular and serological investigation of $2019-\mathrm{nCoV}$ infected patients: implication of multiple shedding routes. Emerg. Microbes Infect. 9, 386-389. doi: 10.1080/22221751.2020.1729071

Zhong, J., Tang, J., Ye, C., and Dong, L. (2020). The immunology of COVID-19: is immune modulation an option for treatment? Lancet Rheumatol. 2, e428-e436. doi: 10.1016/S2665-9913(20)30120-X
Zu, Z. Y., Jiang, M. D., Xu, P. P., Chen, W., Ni, Q. Q., Lu, G. M., et al. (2020) Coronavirus disease 2019 (COVID-19): a perspective from China. Radiology 296, E15-E25. doi: 10.1148/radiol.2020200490

Conflict of Interest: The authors declare that the research was conducted in the absence of any commercial or financial relationships that could be construed as a potential conflict of interest.

Copyright (c) 2020 Patra, Kerry, Maurya, Panigrahi, Kumari and Rout. This is an open-access article distributed under the terms of the Creative Commons Attribution License (CC BY). The use, distribution or reproduction in other forums is permitted, provided the original author(s) and the copyright owner(s) are credited and that the original publication in this journal is cited, in accordance with accepted academic practice. No use, distribution or reproduction is permitted which does not comply with these terms. 